\title{
Spectres of Euripides: Time, Translation and Modernism in H.D.'s Euripides
}

\author{
Harry Strawson ${ }^{1}$ (D)
}

Accepted: 18 December 2020 / Published online: 24 June 2021

(c) The Author(s) 2021

\begin{abstract}
The modernist period was one of intense engagement with antiquity. It was also a period concerned with radical ideas about time put forward by Henri Bergson and Albert Einstein that questioned traditional understandings of the relationship between past and present. This article considers these two aspects of the modernist period through H.D.'s translations of Euripides: it argues that H.D.'s equivocal position in literary modernism and the imagist movement (as demonstrated by her translations from Hippolytus), her prosodic experimentation with Greek verse forms in her translations from Hecuba and Iphigenia at Aulis and finally her emphasis on temporal themes in her Freud-inspired translation of Ion can be all read in such a way to cast new light on the complex temporalities of the translation of classical texts and the modernist reception of the classics.
\end{abstract}

'I seem a very between-worlds person'.-H.D. ${ }^{1}$

In 1915, Gilbert Murray's 1905 translation of Euripides's Troades attained significant popularity ten years after it was first published: it was introduced to American audiences in a successful American production, ${ }^{2}$ while The Daily Telegraph praised Murray for bringing out 'the affinity between the mind of Euripides and the mind of modern Europe'. ${ }^{3}$ We find in this reviewer's comment an echo of a long critical tradition that has often highlighted Euripides's own "in-betweenness" as a playwright caught between

\footnotetext{
${ }^{1}$ Letter 13 May 1925 cited in S.S. Friedman, Penelope's Web: Gender, Modernity, H.D.'s Fiction, Cambridge, 1990, p. 19.

${ }^{2}$ See N.W. Slater, “'The Greatest Anti-War Poem Imaginable”: Granville Barker's Trojan Woman in America', Illinois Classical Studies, 40, 2015, pp. 347-371.

${ }^{3}$ Quoted in F. Wade, Square Haunting: Five Women, Freedom and London Between the Wars, London, 2020, p. 50. See J. Morwood, 'Gilbert Murray's Translations of Greek Tragedy', in Gilbert Murray Reassessed: Hellenism, Theatre, and International Politics, ed. C. Stray, Oxford, 2007, pp. 133-44 for overview of Murray and the surge of interest in Euripides in the early 20th century.
}

\section{Harry Strawson}

harrystrawson1@gmail.com; harry.strawson.17@ucl.ac.uk

1 Department of Greek and Latin, University College London, London, UK 
antiquity and modernity or classicism and decadence. ${ }^{4}$ It is a truism that translation necessarily entails "in-betweenness" via an intermingling of multiple different linguistic, temporal and cultural contexts. If, however, we consider H.D.'s own long engagement with Euripides - whom she described as a "white rose, lyric, feminine" ${ }^{5}$ and whose approach is very different from Murray's — what other affinities might emerge?

In spite of literary modernism's wide-ranging engagement with classical material, scholarship on classical reception in early 20th-century texts remains comparatively rare and new. ${ }^{6}$ The same is true of H.D. and her career-long engagement with Euripides via translation ${ }^{7}$ (which is one of the most sustained and tightly focused instances of classical reception within literary modernism). ${ }^{8}$ In the last couple decades, H.D.'s engagement with ancient Greece more broadly has been approached from a number of angles ${ }^{9}$ and Eileen Gregory's 1997 study in particular has-proceeding from the claim that 'no other modern writer is more persistently engaged in classical literary exchange ${ }^{10}$ - done much to demonstrate the centrality of ancient Greek literature to H.D.'s poetic project. In his 2002 study, Steven Yao approaches H.D.'s translations of Euripides as a means to negotiate and engage with a heavily gendered and exclusionary literary tradition, while recent contributions by M. Hickman and L. Kozak likewise focus on H.D.'s modernist translation largely in terms of gender and erotic desire. ${ }^{11}$ In a short but valuable article from 2019, Eileen Gregory considers H.D.'s translations from the perspective of classical reception and 'Deep Classics'. ${ }^{12}$

In this paper, I build on these studies while broadening and redirecting their focus onto the issue of time and the temporality of classical reception within literary modernism: I take Gregory's 2019 essay as a point of departure as I argue that H.D.'s

\footnotetext{
${ }^{4}$ See A.N. Michelini, Euripides and the Tragic Tradition, Madison, 1987, pp. 1-69. See also A.N. Michelini, 'The Unclassical as Classic: The Modern Reception of Euripides', Poetics Today, 9, 1988, pp. 699-710.

${ }^{5}$ H.D., Notes on Thought and Vision \& The Wise Sappho, San Francisco, 1982, p. 32.

${ }^{6}$ In the last year a number publications have appeared that go some way towards addressing this gap: see N. Worman, Virginia Woolf's Greek Tragedy, London, 2020 and L. Flack, James Joyce and Classical Modernism, London, 2020.

${ }^{7}$ H.D. translated from Euripides's Iphigenia at Aulis, Hippolytus, Bacchae, Hecuba, and Ion between 1916 and 1937 and published an epic poem based on Euripides's Helen in 1961.

${ }^{8}$ In terms of H.D.'s engagement with Euripides via translation, see S.G. Yao, Translation and the Languages of Modernism, New York, 2002, ch. 3; E. Gregory, 'H.D. and Translation', in The Cambridge Companion to H.D., eds. H.J. Chrisodoulides and P. Mackay, Cambridge, 2011, pp. 143-158; M. Hickman \& L. Kozak 'Poppies, scarlet flowers, 'this beauty': H.D.'s Choruses from the Iphigeneia in Aulis and the First World War', Classical Receptions Journal, 10, 2018, pp. 458-475; E. Gregory, 'H.D. and Euripides: Ghostly Summoning', in The Classics in Modernist Translation, eds. M. Hickman and L. Kozak, London, 2019, pp. 121-127; M. Hickman \& L. Kozak, 'Reinventing Eros: H.D.'s Translation of Euripides's Hippolytus', in The Classics in Modernist Translation, eds. M. Hickman \& L. Kozak, London, 2019, pp. 105-120; C. Theis, 'Braving the Elements: H.D. and Jeffers', in The Classics in Modernist Translation, eds. M. Hickman \& L. Kozak, London, 2019, pp. 91-104; J. Westover, 'Repression, Renewal and 'The Race of Women' in H.D.'s Ion', in The Classics in Modernist Translation, eds. M. Hickman \& L. Kozak, London, 2019, pp. 77-90.

${ }^{9}$ See especially E. Gregory, H.D. and Hellenism: Classical Lines, Cambridge, 1997; D. Collecott, H.D. and Sapphic Modernism, Cambridge, 1999.

${ }^{10}$ E. Gregory, H.D. and Hellenism: Classical Lines (n. 9 above), p. 1.

${ }^{11}$ See M. Hickman \& L. Kozak (n. 8 above).

12 E. Gregory 2019 (n. 8 above). For 'Deep Classics' see S. Butler, 'Introduction: On the Origin of 'Deep Classics', in Deep Classics: Rethinking Classical Reception, ed. S. Butler, London, pp. 1-20.
} 
translation project is not only a means to negotiate issues of gender and desire, but also to engage with issues concerning temporality that are both central to her own ambivalent position within mainstream modernism and offer insights into the complex temporality of classical reception itself at a period during which modernists were grappling with radical ideas (particularly in the form of Bergsonian philosophy, Einsteinian physics and Freudian psychology) that questioned classical Newtonian understandings of time and the linear relationship between past and present.

\section{H.D. and Modernist Translation}

The modernist attitude to translation has been noted for its understanding of translation as a 'specific compositional practice' in its own right with the potential of delivering 'cultural renewal'. ${ }^{13}$ The translation of classical texts formed an important part of the related modernist effort to 'revitalise a sense of the literary past' ${ }^{14}$ something Lawrence Venuti has argued often entailed the advancement of a specific modernist cultural agenda. ${ }^{15}$ The modernist practice of translation not only presented the opportunity to revivify English literature, but also to reclaim Greek and Latin classics on its own terms. In George Steiner's observation that 'every generation retranslates the classics', ${ }^{16}$ we find the suggestion that translation-especially of classical texts-is always a site for the contestation of cultural and aesthetic values. The modernist contestation of cultural values via the translation of classical texts was particularly charged and occurred, as Gregory notes, "within an arena in which differing models of 19th-century romantic hellenism confronted the stringent and ascetic classicism proposed by T.E. Hulme, T.S. Eliot and Ezra Pound. ${ }^{17}$

In his essay 'Romanticism and Classicism' (1910-11), T.E. Hulme reframed the inchoate debate between the romantic and the classic in aesthetic terms of 'dry', 'hard' classicism and 'damp', 'soft' romanticism. ${ }^{18}$ Hulme's rejection of aesthetic principles he associated with the romantic hellenism of the past in favour of a modern classicism was one significant aspect of modernist cultural renewal. ${ }^{19}$ The essay informed the modernist cultural agenda and classicism espoused by Pound and Eliot in their rejection of 19th-century poetry and also informed Pound's later prescriptive remarks regarding imagism. ${ }^{20}$ It has not gone unnoticed that Hulme's essay recast literary tradition in decidedly gendered terms ${ }^{21}$ (hence Gregory's observation that 'to understand H.D.'s marginal status in literary modernism', one must understand the

\footnotetext{
13 S.G. Yao, Translation and the Languages of Modernism (n. 8 above), p. 6.

14 E. Gregory, 'H.D. and Translation' (n. 8 above), p. 145.

15 L. Venuti, The Translator's Invisibility: A History of Translation, New York, 1995, pp. 187-8.

16 G. Steiner, After Babel, Oxford, 1975, p. 30.

17 E. Gregory, 'H.D. and Translation' (n. 8 above), p. 145.

18 T.E. Hulme, Speculations: Essays on Humanism and the Philosophy of Art, London, 1924.

19 E. Gregory, 'H.D. and Translation' (n. 8 above), p. 144.

${ }^{20}$ See E. Gregory, H.D. And Hellenism: Classical Lines, (n. 9 above), pp. 15-22.

21 See D. Collecott, H.D. and Sapphic Modernism (n. 9 above); C. Laity, H.D. and the Victorian Fin de Siècle: Gender, Modernism, Decadence, Cambridge, 1996; E. Gregory, H. D. and Hellenism: Classical Lines (n. 9 above).
} 
romantic and classic issue). ${ }^{22}$ In a detailed outlining of the implications of Hulme's essay, Gregory shows how mainstream modernists organised a series of binary distinctions that mapped onto the romantic-classic division and that such oppositions as hard-soft; dry-wet; impersonal-personal; ordered-chaotic; fixity-flux; masculinefeminine emerged as guiding principles of modern classicism. ${ }^{23}$ It is striking—and no doubt deliberate - that when Pound and F.S. Flint came to delineate the precepts of imagism as they understood it in their respective 1913 articles "Imagisme" and "A Few Don'ts by an Imagist", they echoed the vocabulary in Hulme's description of the classic as 'hard' and 'dry'. In view of this gendered aesthetic approach, there is a certain irony in the fact that it was to a large extent a woman who leant imagism (in Pound's phrase) its 'Hellenic hardness. ${ }^{24}$ The influence of Pound's and Flint's 1913 articles has distorted the story of imagism somewhat and obscured H.D.'s own formative role in the movement. This is especially the case with regard to imagism's engagement with antiquity: 'Imagism is not inherently tied to the classical tradition ... but $\mathrm{H}$. D. and her classical concerns would in many ways dominate and help to shade notions of Imagism as a whole, as is evident in the multiple classical references that Pound makes in his "A Few Don'ts" essay'. ${ }^{25}$ It seems that H.D.'s influence contributed to comments such as Flint's description of imagism not as a 'revolutionary school' but as an attempt to 'write in accordance with the best tradition' ${ }^{26}$ as headed by classical poets. 'If you want the gist of the matter,' wrote Pound in a similar vein, 'go to Sappho, Catullus'. ${ }^{27}$ The three principles for would-be imagists as set out by Flint demanded directness ("direct treatment of the "thing" whether subjective or objective'); economy ('use absolutely no word that did not contribute to the presentation'); and rhythm ('compose in sequence of musical phrase, not in sequence of a metronome'). ${ }^{28}$ These three directives stand in opposition to the principal pathologies Pound and Hulme identified in 19th-century poetry: linguistic indeterminacy, verbosity and strict metrical rhyming schemes. ${ }^{29}$

\footnotetext{
${ }^{22}$ E. Gregory, H.D. and Hellenism: Classical Lines (n. 9 above), p. 15.

${ }^{23}$ Ibid., 15-22.

${ }^{24}$ Quoted in C. Hadjiyiannis, 'Ezra Pound, T. E. Hulme, Edward Storer: Imagism as Anti-Romanticism in the Pre-Des Imagistes Era', in Imagism: Essays on Its Initiation, Impact and Influence, eds. J. Gery, D. Kempton, \& H. Stoneback, New Orleans, 2013, pp. 17-30 (21). The full quotation is 'the Hellenic hardness of H.D.'s poems'. It was also H.D. (along with Richard Aldington) whose poetry inspired Pound's proto-imagist appraisal in 1912: 'objective—no slither; direct—no excessive use of adjectives; no metaphors that won't permit examination. It's straight talk, straight as the Greek!' quoted in D. Ayers, Modernism: A Short Introduction, Hoboken, 2004, p. 2.

${ }^{25}$ B. Brinkman \& B. Brinkman, "Educating the "Perfect Imagist": Greek Literature and Classical Scholarship in the Poetry of H.D.', in Brill's Companion to the Reception of the Classics in International Modernism and the Avant-garde, eds. A.J. Goldwyn \& J. Nikopoulos, Leiden, 2016, pp. 38-52 (40).

${ }^{26}$ F.S. Flint, 'Imagisme', Poetry: A Magazine of Verse, 1, 1913, pp. 198-200.

27 E. Pound, 'A Few Dont's By an Imagist', Poetry: A Magazine of Verse, 1, 1913, pp. 200-6.

${ }^{28}$ F.S. Flint, 'Imagisme' (n. 26 above), p. 199. Notably the imagist programme is not unlike the guidelines Matthew Arnold provided for would-be translators of Homer: 'eminently rapid; ... eminently plain and direct'. See M. Arnold On Translating Homer: Last Words, London, 1862.

${ }^{29}$ See T.S. Eliot, 'Euripides and Professor Murray', in Selected Essays 1917-1932, London, 1951, pp. 59-64 (60-1); C. Laity, H.D. and the Victorian Fin de Siècle: Gender, Modernism, Decadence (n. 21 above), p. 21.
} 
One further important aspect of the romantic-classic distinction overlooked by Gregory relates to contemporary ideas concerning time-and specifically, those recently introduced by the work of Bergson and Einstein. ${ }^{30}$ In Wyndham Lewis's 1927 polemic against the so-called 'time-mind', Bergsonian time (to which we return below) represents 'all that is degenerate in art: flux, change, romanticism, the crowd and the unconscious' ${ }^{31}$ Lewis viewed emergent ideas concerning time in terms of the romantic-classic dichotomy and saw Bergsonian 'psychological time' as 'essentially the time of the true romantic' in its rejection of distinct temporal categories. ${ }^{32}$ The temporal demands of classicism, as Lewis saw them, are reflected in Pound's ideal of an imagist poem as the 'instantaneous presentation' of 'an intellectual complex in an instant of time' that grants 'freedom from time limits' ${ }^{33}$ This 'instantaneous presentation' is ably demonstrated in Pound's own famous imagist poem 'In the Station of the Metro': 'The apparition of these faces in the crowd: / Petals on a wet, black bough'. ${ }^{34}$ The poem, we might note, contains no verbs and so avoids all sense of temporal movement in its pursuit of timeless instantaneity. In spite of Pound's markedly modern subject matter, the epigrammatic instantaneity or "timelessness" of its formal presentation aligns it with traditions imagists tended to associate with antiquity. The return to classical aesthetic tenets did not (for Pound et al.) represent the more romantic "timefullness" of flux between past and present in which both could exist simultaneously: it represented instead a fixed and linear continuation or tradition of classical aesthetics and an understanding of time that rejected the temporal indeterminacy of romanticism.

The imagist movement as theorised by Pound, Flint and Hulme can be seen as a vehicle for classical aesthetic and temporal principles consistent with the programme of cultural renewal pursued by mainstream modernists. The inaugural 1914 imagist anthology, Des Imagistes, contained numerous translations from classical texts (including four by H.D.) that could, in Venuti's terms, serve as an 'absolute value' by which to reject 'translations informed by competing agendas'. ${ }^{35}$ We encounter precisely this strategy at work in Eliot's use of H.D. as a foil in a negative review of Murray's translations of Euripides, in which he writes: 'The choruses from Euripides of H.D. are ... much nearer to both Greek and English than Mr. Murray's' ${ }^{36}$ Let us compare the two translations of Hippolytus 121-134. Here's Murray:

\footnotetext{
${ }^{30}$ Henri Bergson developed his notion of 'duration' in his 1889 text (translated into English in 1910) Time and Free Will, while Einstein published his general theory of relativity in 1915. See L.D. Henderson, 'Modernism and Science', in Modernism: Volume 1, eds. A. Eysteinsson \& V. Liska, Amsterdam, 2007, pp. 383-405 for modernist notions of time. Nb. T.E. Hulme was a translator of Bergson and translated his An Introduction to Metaphysics into English in 1912.

31 K. Doosten, 'Time and Western Man', The Modernism Lab at Yale University < https://modernism. coursepress.yale.edu/time-and-western-man/> [Accessed 22/03/20], 2009.

32 W. Lewis, Time and Western Man, London, 1927, p. 24.

33 E. Pound, 'A Few Dont's By an Imagist' (n. 27 above), p. 200.

34 E. Pound, 'In the Station of the Metro', Poetry: A Magazine of Verse, 2, 1913, p. 12.

35 L. Venuti, The Translator's Invisibility: A History of Translation (n. 15 above), p. 189.

36 T.S. Eliot, 'Euripides and Professor Murray (1918)' (n. 29 above), p. 63.
} 
There riseth a rock-born river,

Of Ocean's tribe, men say;

The crags of it gleam and quiver,

And pitchers dip in the spray:

A woman was there with raiment white

To bathe and spread in the warm sunlight,

And she told a tale to me there by the river

The tale of the Queen and her evil day:

How, ailing beyond allayment,

Within she hath bowed her head,

And with shadow of silken raiment

The bright brown hair bespread.

For three long days she hath lain forlorn,

Her lips untainted of flesh or corn,

For that secret sorrow beyond allayment

That steers to the far sad shore of the dead. ${ }^{37}$

And H.D.:

At high-tide, the sea - they say -

left a deep pool

below the rock-shelf:

in that clear place

where the women dip

their water-jars,

my friend steeped her veils

and spread the scarlet stuff

across the hot ridge

of sun-baked rocks:

she first brought word

of my mistress:

"She lies sick,

faint on her couch within the palace;

her thin veils

cast a shadow

across her bright locks.

I count three days

since her beautiful lips

touched the fine wheat -

her frail body

${ }^{37}$ G. Murray, The Hippolytus of Euripides, New York, 1909-1914. 
disdains nourishment:

she suffers -

some secret hurt

hastens her death. ${ }^{38}$

It should be noted at the outset that already by the end of 1914 H.D. was seeking to distance herself from imagism as theorised by Pound and wrote in a letter: 'Our great \& good friend is taking up 'Imagism' again-don't you think we'd better drop it? . . . E. P. [Ezra Pound] is making it ridiculous' ${ }^{39}$ It is with this resistance in mind that we can best appreciate the different aesthetic registers at work even if, at first glance, H.D.'s translation appears to be a model of modern classicism and imagist poetics. Its rejection of metronomic iambs, regular rhyme scheme and poeticisms and its irregular lineation immediately stand out from Murray's translation. In comparison with Murray, H.D. meets all the imagist criteria: she is more economical (ninety-two words to one-hundred-and-ten); more direct (ten adjectives to fourteen and only eleven conjunctions and prepositions compared with Murray's twenty-six) and composes in irregular cadence rather than regular metre. The obscurity of $\omega \kappa \varepsilon \alpha \nu$ o $\tilde{~ i s ~ r e p l a c e d ~ w i t h ~ a n ~ e v e r y d a y ~ w o r d ; ~ t h e ~ d e i c t i c ~ a d v e r b ~} \tau$ ó $\theta \imath$ becomes 'in that clear place' to emphasise light and clarity. The short broken lines mimic the organisation of the Greek text on the page. In the most striking alteration, the description of a gushing stream and its romantic connotations of watery flux (H.D.

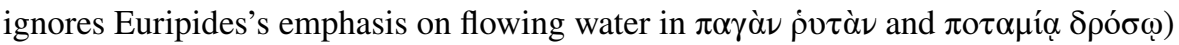
is swapped for the better imagist figure of a rock pool: a crystalline image whose wateriness is tempered by an emphasis on rock.

In spite of H.D. exemplifying imagist principles in some formal aspects of her translation, other formal aspects, as well as its content, offer an insight into how H.D.'s imagism departs from the principles outlined by Pound and Flint. While the opening line 'at high-tide' marks a discrete moment in time and captures the instantaneity preferred by Pound (as do the series of "hard" images that flash up, isolated by line breaks, in the course of the translation: e.g. 'a deep pool', 'the rock-shelf', 'the hot-ridge'), the initial impression of timeless instantaneity is quickly undone in the following line. The sibilance of 'the sea-they say' is evocative of the sea and creates an impression that is far from temporally discrete: the sound of the sea does not belong to a specific moment but comprises (and collapses) past, present and future in its universality. The sibilance of the line evokes Lewis' 'time of the true romantic' in its flux and elision of distinct temporal categories while resisting the easy location of Euripides in the past (unlike Murray's metronomic and archaising 'of Ocean's tribe, men say').

The translation's content and its focus on Phaedra and the more romantic themes of uncontrolled passion - as well as its hints of late 19th-century sensibilities regarding sexual morals - also refuses to sit easily with imagist precepts as outlined by Pound. In

\footnotetext{
38 H.D., Choruses from the Iphigenia in Aulis and the Hippolytus of Euripides, London, 1919.

39 Letter to Amy Lowell dated December 17, 1914 quoted in L. Mattison, 'H.D.'s Institutional imagism: Memory, Desire, and the Image in Process', in Understanding Bergson, Understanding Modernism, eds. P. Ardoin, S.E. Gontarski, \& L. Mattison, London, 2013, pp. 228-242 (228).
} 
terms of H.D.'s inclusion of more romantic themes, one recent analysis highlights her emphasis on veiling and the colour red in her translations of $\varphi \alpha ́ \rho \varepsilon \alpha$ (usually typically translated as 'cloths') and $\pi о \rho \varphi v ́ \rho \varepsilon \alpha$ (usually translated as 'red', 'crimson', or 'purple') insofar as it suggests 'H.D.'s interest in modesty and privacy culturally associated with women's veiling' while her focus on 'scarlet' suggests 'scarlet letters and scarlet women' ${ }^{40}$ The latter suggestion carries a strong overtone of late 19th-century sexual morals and while it has been analysed in terms of gender, it also adds another temporal layer to H.D.'s translation. It is a further way in which the translation forgoes 'instantaneity' and incorporates multiple coexisting time-frames into one text: H.D. refigures Phaedra's shame in Euripides in terms of late 19th-century sensibilities while also presenting it in 'hard' Hulmean imagist verse (the 'scarlet stuff', we might note, is spread 'across the hot-ridge / of sun-baked rocks'). The overlaying of these different temporal registers (antiquity, late 19th century, modernity) is indicative of H.D.'s resistance to the prescribed 'instantaneity' of imagist poetics. The choice of Euripides, whose association with decadent poetics jarred with Hulme's modern classicism, ${ }^{41}$ is also an important component of H.D.'s subversion of imagist cultural politics as set out by Pound et al. It is arguably H.D.'s most obvious indication of her enduring interest in romantic hellenism and Gregory writes that her 'choice of texts and writers, in the context of modern classicism, was politically resistant, focusing on ... classical poets associated with a 'feminine' tradition'. ${ }^{42}$ When H.D. describes Euripides as a 'white rose, lyric, feminine', ${ }^{43}$ she not only seems to confirm Hulme's pejorative description of romanticism as 'roses, roses, roses, all the way ${ }^{44}$ but also the prevailing view at the turn of the 20th century that associated Euripides with the feminine and decadent romantic hellenism of Walter Pater and Oscar Wilde. ${ }^{45}$

It is possible to appreciate the effect that the dual-nature of H.D.'s translation had on her modernist peers in Eliot's own dismissal of Murray and lukewarm appreciation of H.D.'s efforts. While Eliot writes that 'Murray has simply interposed between Euripides and ourselves a barrier more impenetrable than the Greek language', his praise of H.D.'s choruses in comparison is nonetheless tempered with the proviso 'allowing for errors and even occasional omissions of difficult passages'. Eliot is by no means oblivious to the dissenting force of H.D.'s translation in terms of his own modernist aesthetics and comments that she and the other translators in The Poets' Translation Series (where H.D.'s translation appeared) ${ }^{46}$ had merely translated some

\footnotetext{
${ }^{40}$ M. Hickman \& L. Kozak, 'Reinventing Eros: H.D.'s Translation of Euripides's Hippolytus' (n. 8 above), p. 112.

41 See J.A. Symonds, Studies of the Greek Poets, London, 1902 [3rd. edn.], pp. 29f. for a Victorian view of Euripides's decadence; cf. E. Gregory, H. D. And Hellenism: Classical Lines (n. 9 above), pp. 23-8; A.N. Michelini, Euripides and the Tragic Tradition (n. 4 above), p. 68.

42 E. Gregory, 'H.D. and Translation' (n. 8 above), p. 146; see D. Collecott, H. D. and Sapphic Modernism (n. 9 above), pp. 9-33. Nb. Douglas Bush's criticism that 'the hard bright shell of H.D.'s poetry partly conceals a soft Romantic nostalgia ... of the Victorian Hellenists' in D. Bush, Mythology and the Romantic Tradition in English Poetry, London, 1937, p. 505.

${ }^{43}$ H.D., Notes on Thought and Vision \& The Wise Sappho (n. 5 above), p. 32.

44 T.E. Hulme, Further Speculations, ed. Sam Hynes, Minneapolis, 1955, p. 69.

45 See E. Gregory, H.D. and Hellenism: Classical Lines (n. 9 above), p. 25.

46 See E. Vandiver, 'Seeking ... Buried Beauty': The Poets' Translation Series', in The Classics in Modernist Translation, eds. M. Hickman \& L. Kozak, London, 2019, pp. 7-18.
} 
of the 'more romantic crumbs of Greek literature': 'None of them', he remarks, 'has yet shown himself competent to attack the Agamemnon'. ${ }^{47}$

The conversation we see playing out here between Murray, H.D. and Eliot in regard to translation is a fine example of Venuti's notion of the importance of translation to the advancement of a certain modernist agenda. In his study of modernist translation, Venuti develops an implicit distinction between what I term first-order and second-order domestication. Essentially all translation engages in first-order domestication insofar as it entails 'an exchange of foreign-language intelligibilities for those of the translating language' ${ }^{48}$ It is the target language where issues of foreignisation and domestication are most at stake: does the translated text signal its (linguistic, temporal, cultural) otherness or disguise it? In the case of modernism, it is typically the former as translators pursue the apparent foreignisation of the source text in service of cultural renewal. Yet in Venuti's analysis this serves simultaneously as a second-order domestication by inscribing its own cultural agenda onto the translated text. The paradox here is that foreignisation ultimately becomes a tool of second-order domestication. ${ }^{49}$ Modernist translation therefore represents an instance of narrow domestication via broad foreignisation: it domesticates texts according to its own cultural politics even as it foreignises within wider contexts. It is in view of these mechanics of translation and cultural politics that H.D.'s complex translations can best be understood. H.D. essentially pushes the paradox further and engages in a translational triple-bluff by incorporating elements of both modern classicism and romantic hellenism: H.D. foreignises (and thus domesticates) texts in line with a mainstream imagist cultural agenda while simultaneously enacting the same process in the opposite direction as she foreignises (and thus domesticates) texts in line with the cultural agenda of romantic hellenism. It is a kind of double-movement that reflects H.D.'s synthesis of competing agendas to produce culturally composite translations.

It is possible to see this process at work not only in H.D.'s translations (as demonstrated by her Hippolytus) but also in the theoretical approaches to translation that H.D. occasionally outlines in her prose works. One useful example is the account of translation offered in H.D.'s novel Bid me to Live (1960) by her autobiographical translator-protagonist, Julia Ashton: ${ }^{50}$

She was self-effacing in her attack on those Greek words, she was flamboyantly ambitious. The words themselves held inner words, she thought. If you look at a word long enough, this peculiar twist, its magic angle, would lead

\footnotetext{
${ }_{47}$ T.S. Eliot, 'Euripides and Professor Murray' (n. 29 above), p. 63.

48 L. Venuti, The Translator's Invisibility: A History of Translation (n. 15 above), p. 177.

49 See ibid., 188f: 'Modernism seeks to establish the cultural autonomy of the translated text by effacing its manifold conditions and exclusions, especially the process of domestication by which the foreign text is rewritten to serve modernist cultural agenda ... as the absolute value that exposes the inadequacy of translations informed by competing agendas.'

50 See E. Gregory 2011, 'H.D. and Translation' (n. 8 above), p. 143: 'In autobiographical fictions-especially 'Hipparchia' in Palimpsest (1926) and Bid Me to Live (1960)—she figures herself as a translator of classical poetry, an activity that in these narratives seems almost indistinguishable from original composition.'
} 
somewhere, like that Phoenician track, trod by the old traders. She was a trader in the gold, the old gold, the myrrh of the dead spirit.

She was bargaining with each word. She brooded over each word, as if to hatch it. Then she tried to forget each word, for "translations" enough existed and she was no scholar. She did not want to "know" Greek in that sense. 51

It is perfectly possible that H.D., who was working on the manuscript of Bid me to Live between 1939 and $1950,{ }^{52}$ had Eliot's comment regarding the Agamemnon in mind when she wrote this passage (cf. 'her attack on those Greek words'). The passage is illuminating insofar as it confirms some of the inferences we drew from H.D.'s translation of Hippolytus regarding her culturally composite translation: its blurring of gendered approaches to translation (the masculine 'attack on those Greek words' and feminine 'she brooded over each word, as if to hatch it') also extends to the blurring of cultural and temporal barriers. The wavering between ambition and modesty ('self effacing ... flamboyantly ambitious') recalls the political dimension of Hulme's essay in which modern classicism is predicated on an awareness of human limitations, while ambition evokes romantic optimism. ${ }^{53}$ The passage also undermines temporal and spatial distinctions as Julia Ashton equates the Greek words with a 'Phoenician track' (allegedly first made by 'Phoenician donkeys' and 'ancient sandals' $)^{54}$ and suggests that the words can lead from past to present or from 20th-century England to ancient Phoenicia. The contradictions in the passage-insofar as they outline a tension between masculine and feminine; modern classicism and romantic hellenism; antiquity and modernity-naturally align themselves with H.D.'s own translation practice as evidenced in her translation from Hippolytus. In the case of both H.D. and Julia Ashton we get the sense of translation as a means to successfully incorporate binary distinctions in culturally and temporally composite translations.

In the picture that emerges from H.D.'s writings on translation itself, it does not appear that she saw translation first and foremost a linguistic exercise but rather as a more intuitive, holistic and embodied act. The idea of looking carefully at Greek words and conceiving of them as a 'track' is reflected in her comments elsewhere that 'I know we need scholars to decipher and interpret the Greek, but we also need poets and mystics and children ... to see through the words' and 'these [Greek] words are portals to me, gates' ${ }^{55}$ It is worth pausing, at this point, to briefly consider where exactly might these 'portals' and 'gates' (or the 'Phoenician track') lead?

\footnotetext{
51 H.D., Bid me to Live (A Madrigal), New York, 1960, p. 162.

52 See C. Laity, H.D. and the Victorian Fin de Siècle: Gender, Modernism, Decadence (n. 21 above), p. 147.

53 See T.E. Hulme, Speculations: Essays on Humanism and the Philosophy of Art (n. 18 above), p. 116: in Hulme's understanding romanticism views the individual as 'an infinite reservoir of possibilities' while classicism accepts that 'man is an extraordinarily fixed and limited animal'.

54 H.D., Bid me to Live (A Madrigal) (n. 51 above), pp. 143, 147.

55 H.D., Notes on Euripides (unpublished), pp. 8-9. Quoted in E. Gregory H.D. and Hellenism: Classical Lines (n. 9 above), p. 68.
} 
In her 1919 essay 'Notes on Thought and Vision', H.D. develops an esoteric theory of an 'over-mind' or 'over-world' consciousness: it is significant not only that H.D. states that 'the realization of this over-conscious world is the concern of the artist' but also that 'certain words and lines of Attic choruses ... are straight, clear entrances, to me, to over-world consciousness' ${ }^{56}$ It would seem that Greek acts as an entry point to 'the world of the great creative artists', which H.D. adds 'is never dead'. ${ }^{57}$ In this comment H.D. implies the special temporal status of art and goes on to suggest the nature of Euripides's relationship to it: the over-conscious world of art exists concurrently with the everyday world while 'the Attic dramatist' can act as a bridge between the two via the 'eternal, changeless ideas he had grown aware of, dramas already conceived that he had watched' ${ }^{58}$ It is important to note that the 'Attic dramatist' (sc. Euripides) is not the author of these 'eternal' ideas (H.D. indicates that they are anterior to Euripides himself), but rather a particular manifestation of them or vehicle for their expression. The plays of Euripides are not themselves eternal but rather temporally composite in their bearing on the everyday world as well as on certain eternal ideas simultaneously. When H.D. refers to Greek words as 'gates' or 'portals', it seems she sees them as a way to access the 'world of great creative artists' that exists in multiple temporalities and is central to her own understanding of art. It is to this notion of coexisting temporalities within a world of art that 'is never dead' that I now turn in more detail.

\section{Spectres of Euripides}

'We are all haunted houses'.--H.D. ${ }^{59}$

It is something of a critical commonplace to conceptualise translation as a form of resurrection $^{60}$ and this was especially true of modernist translators (as Pound put it bluntly in a comment on his Homage: 'My job was to bring a dead man to life'). ${ }^{61}$ We encounter a similar emphasis with regard to H.D. in Eliot's hatchet-job on Murray as he attacks Murray's failure to sufficiently "resurrect" the Greek playwright while praising H.D. for drawing 'sustenance from the dead' ${ }^{62}$ It is with this in mind that we might consider a 2008 study in which Michael Golston demonstrated that, pre-audio recording, the prosodic features of a poem were considered the remains of

\footnotetext{
56 H.D., Notes on Thought and Vision \& the Wise Sappho (n. 5 above), pp. 40, 24.

57 Ibid., p. 24.

58 D. Collecott, H.D. and Sapphic Modernism (n. 21 above), p. 104; H.D., Notes on Thought and Vision \& The Wise Sappho (n. 5 above), p. 23.

59 H.D., Tribute to Freud, Manchester, 1970, p. 146.

60 See S. Bassnett, 'Prologue', in Tradition, Translation, Trauma: The Classic and the Modern, eds. J. Parker \& T. Matthews, Oxford, 2011, pp. 1-9; M. Reynolds, The Poetry of Translation: From Chaucer \& Petrarch to Homer \& Logue, Oxford, 2011, pp. 237f.

61 E. Pound, The Selected Letters of Ezra Pound 1907-1941, New York, 1971, p. 211.

62 T.S. Eliot, 'Classics in English', Poetry: A Magazine of Verse, 9, 1916, pp. 101-4 (103). Cf. Eliot, 'Euripides and Professor Murray' (n. 29 above), p. 64: 'It is because Professor Murray has no creative instinct that he leaves Euripides quite dead.'
} 
a poet's voice after death: ${ }^{63}$ if translation aims at resurrection, ${ }^{64}$ then what could be more effective than giving a poet back his voice?

I ask this question because it situates my concerns here-viz., the relationship between prosody and temporality in translation-within the context of a ghostly understanding of translation. ${ }^{65}$ The translations of Euripides by H.D. (as Yopie Prins and Orla Polten have shown $)^{66}$ experiment with prosody via the incorporation of Greek metrical cola into free verse. If we consider her attempts to mimic the metrical effects of Euripidean odes, we can see H.D. as engaging in a prosodic summoning of the Greek playwright. It is here that the temporal dimension of Derridean hauntology ${ }^{67}$ is helpful insofar as ghosts represent an incursion of the past into the present that challenges a 'temporality made up of successive linking presents'. ${ }^{68}$ While some translations might obscure these multiple temporalities ("domesticating" translation might bring a text into the present; "foreignising" translation might preserve its pastness via archaisms), ${ }^{69}$ I argue that H.D.'s handling of prosody can be understood as making explicit the implicit fact that a translation always contains more than one temporality in a deliberate attempt to disrupt linear patterns of time.

\section{Prosody and Hauntology}

In the first of the three interlocking novellas published in H.D.'s Palimpsest (1926), 'Hipparchia', H.D. presents an engagement with the past-mediated via translation and prosody - that can be read in hauntological terms. The translator-protagonist of 'Hipparchia' is an eponymous Greek courtesan haunted by Euripidean choruses

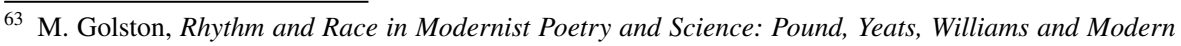
Sciences of Rhythm, New York, 2008, pp. 1-54; see O. Polten 'Spectres of Metre: English Poetry in Classical Measures, 1860-1930', PhD diss., University of Cambridge, 2018, p. 217.

${ }^{64}$ Cf. J.C. Hayes, 'Temporality, Subjectivity, and Neoclassical Translation Theory: Dryden's Aeneis', Restoration: Studies in English Literary Culture 1660-1700, 26, 2002, p. 113: 'Translation projects are fuelled by ... desire to recreate past writers, to make them speak again in one's own voice'.

${ }^{65}$ Michael Emmerich picks up on this hauntological dimension of translation in his conception of translator-as-ghost: '[The translator is] a ghost who haunts languages, cultures, and nations, existing in two worlds at once but belonging fully to neither. The translator, as a ghost, is neither wholly domestic nor wholly foreign, because she is simultaneously both foreign and domestic'. See M. Emmerich, 'Beyond, Between: Translation, Ghosts, Metaphors', in In Translation: Translators on their Work and What it Means, eds. E. Allen \& S. Bernofsky, New York, 2013, pp. 44-57 (50).

${ }^{66}$ See O. Polten, 'Spectres of Metre: English Poetry in Classical Measures, 1860-1930', PhD diss., University of Cambridge, 2018., ch. 5; Y. Prins, Ladies' Greek: Victorian Translations of Tragedy, Princeton, 2017, pp. 180-201.

${ }^{67}$ See J. Derrida, Spectres of Marx: The State of Debt, the Work of Mourning and the New International, London, 1994. Derrida outlines "hauntology" as the temporal and ontological disjointedness that occurs when an apparently present being or entity is revealed to be absent.

${ }^{68}$ P. Buse \& A. Stott (eds.), Ghosts: Deconstruction, Psychoanalysis, History, London, 1999, p. 17.

${ }^{69}$ E.g. Pound's Cavalcanti translations. See L. Venuti, The Translator's Invisibility: A History of Translation (n. 15 above), pp. 191-208.
} 
(specifically Hecuba 444-54) and who translates Greek literature for her Roman lovers/oppressors:

She came back to Euripidean choros. Euripidean choros seemed to fit simply her surroundings, ${ }^{70}$ part simply of the landscape as that gentle, subtle lap-lap of the almost tideless ocean that beat a metre so fine, so subtle, so etherealised that one could scarcely count it. ${ }^{71}$

We might note at the outset that it is not only Hipparchia who keeps coming 'back to Euripidean choros' but also H.D. herself: it is a feature of H.D.'s classical reception and Hickman and Kozak write that the 'Greek tragic chorus draws her in part because it tends to be composed of marginalized community members who would not go into battle, such as women, foreigners, and old men'. ${ }^{72}$ The interest in choral odes can also, however, be understood in metrical and temporal terms insofar as Greek choruses employ more variable and expressive metres than other parts of a tragedy. The chorus (which H.D. refers to elsewhere as a play's 'collective conscience' $)^{73}$ is also simultaneously both central and peripheral to the action and, in temporal terms, can be seen as existing both within the dramatic time of the play and outside of it as the chorus reflects upon the temporally discrete action of the play in more temporally ambiguous and general terms. The fact that H.D. can successfully excise Euripidean choruses from their plays as stand-alone translations is an implicit recognition of their temporal ambiguity. It may therefore be suggested that H.D. was drawn to Euripidean choruses not simply because of the focus on marginalised groups but also because it was better suited to her interests in non-linear notions of temporality.

In the case of 'Hipparchia' this idea of non-linear temporality is reflected by the fact that - as Gregory notes ${ }^{74}$ — a radical chronological inconsistency lies at the centre of the novella. Although captured in $75 \mathrm{BC}$ during Roman incursions into Macedonia, Hipparchia herself claims as parents the cynic Hipparchia of Maroneia (fl. 325 BC) and Crates of Thebes (c. 365-285 BC) who lived in the 4th-century BC. The family tree therefore collapses a gap of two-and-a-half centuries. This is unlikely to be a mistake: Gregory notes that H.D. studied ancient historians while Hipparchia herself engages in historiography (she possesses manuscripts of an 'unfinished history of the Macedonian conquest'). ${ }^{75}$ Instead the narrative overlays the Macedonian (4th-century BC) and Roman (2nd-century BC) conquest of Greece-and implies that Hipparchia represents a third (1st-century BC) subjugation of Greece via cultural exploitation in a palimpsestic conception of history. ${ }^{76}$ (It is perhaps significant that Hipparchia's manuscripts of the history of the Macedonian conquest remain

\footnotetext{
70 This phrase recurs throughout 'Hipparchia'. Cf. pp. 73, 79.

71 H.D., Palimpsest, Carbondale, 1968, p. 38.

72 Hickman \& Kozak, 'Poppies, scarlet flowers, 'this beauty': H.D.'s Choruses from the Iphigeneia in Aulis and the First World War' (n. 8 above), p. 467.

73 H.D., Hippolytus Temporizes \& Ion, New York, 2003, p. 166.

74 Gregory, H.D. and Hellenism: Classical Lines (n. 9 above), p. 61.

75 Ibid., p. 266 n. 45.

76 Ibid., p. 60 for timeline.
} 
'unfinished': it is indicative of Hipparchia's/H.D.'s temporal perspective that refuses to view the past in a traditional or linear sense). The refrain from Hecuba-since it 'fits simply' Hipparchia's situation as a war spoil—contributes a further "historical" layer in the c. 1200 BC fall of Troy and subjugation of Trojan women. The consequence of this historical layering effectively sees H.D. situate Hipparchia in an ontological, historical and temporal no-man's-land that results in a kind of "hauntological" collapse as she works on her translations:

Where was she? What was she? ... Who was she? Mind, body, experience past and present, her intellectual experiences, the fervour of her manuscripts, all seemed merged now ... The old stately metres hammered in her skull. Her feet quickened out of proportion to its measured beating. Metres formed and reformed in her head. Past and present formed and reformed ... Metres, memories formed and reformed. ${ }^{77}$

It is revealing that Hipparchia associates metre with time and H.D. maps Hipparchia's temporal-ontological disjunction against a tension between 'measured beating' and 'quickened' feet. ${ }^{78}$ If we follow Prins' analysis of H.D.'s closet-drama Hippolytus Temporizes (1927) ${ }^{79}$ as a metrical conflict opposing regular iambs (sc. 'measured beating') to more expressive metres (sc. 'quickened' feet), ${ }^{80}$ we can likewise read this passage in terms of prosodic conflict. In the closet-drama, Hippolytus rejects verse "patterned on iambics" ${ }^{81}$ : 'Feet, feet, feet, feet, / what of the head, the heart, the frenzy that swims up like sudden tide / Of full storm-sea / At sun-down? ${ }^{82}$ In Palimpsest, Hipparchia displays a similar preference for expressive metres by defying the 'heavier language' and preserving the 'honeyed delicacy of curious vowel symbol'. ${ }^{83}$ In spite of the 'neat fitting of pallid mosaic' required by the heavier foreign language, Hipparchia's/H.D.'s translation of Hecuba 444-8 strives to preserve the lighter Euripidean metre:

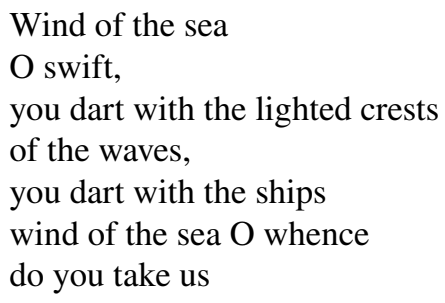

\footnotetext{
$\overline{77 \text { H.D., Palimpsest (n. } 71 \text { above) }}$, p. 76.

${ }^{78}$ We might also infer the implicit question: when was she?

${ }^{79}$ We should note that H.D. was working on Hippolytus Temporizes at the same time as her prose work Palimpsest. See H.D.'s remark 'I was working at prose too, and I must return to that sometime ... Palimpsest is what I am thinking of, published in 1926, in Paris. I must have been working on the two, the poetry and the prose, at about the same time' quoted in W. Wenthe, "'The Hieratic Dance": Prosody and the Unconscious in H.D.'s Poetry', Sagetrieb, 14, 1995, pp. 113-140 (116).

${ }^{80}$ See Prins, Ladies' Greek: Victorian Translations of Tragedy (n. 66 above), pp. 195-7.

${ }^{81}$ H.D., Hippolytus Temporizes \& Ion, New York, 2003, p. 40.

82 Ibid., 41.

${ }^{83}$ H.D., Palimpsest (n. 71 above), p. 72.
} 
unfortunate $?^{84}$

It may be that transposing quantitative Greek verse perfectly into accentual English verse is impossible ${ }^{85}$ but something of the effect can be evoked by replacing quantitative patterns with accentual patterns. ${ }^{86}$ If we substitute sound-quantity for sound-quality, we can detect a pattern of choriambs (introduced by 'wind of the sea') offsetting the natural iambic quality of the 'heavier [English] language" ${ }^{87}$ and preserving something of the aeolic character of Euripides's original. ${ }^{88}$ The aeolic metrical pattern in this case is established by a series of choriambs ("wind of the sea', 'crests / of the waves', 'dart with the light', 'dart with the ships') that ends emphatically with the ringing echo of 'unfortunate'. ${ }^{89}$

Hipparchia identifies these choral lines as 'fit' for her surroundings_-yet in light of Gregory's overview of Hipparchia's palimpsestic historical and temporal situation, the metrical resonance actually extends much further. The relevant surroundings include not only the dramatic context of 1200 BC Troy and historical context of war-time 5th-century Athens, but also Macedonia's sack of Thebes and Rome's sack of Corinth as well as Hipparchia's own capture and displacement in 75 BC. In Hipparchia's/H.D.'s Euripides, metre is not a way to measure time in a linear sense but rather to simultaneously inhabit multiple temporalities. It is notable that the final lines of the chorus, in spite of being bracketed with choriambic phrases, also offers itself as a very regular iambic pentameter following 'wind of the sea' if we discount the line breaks: 'O whence / do you take us / unfortunate?' If we sound the lines, it is possible to hear the tension or conflict between the 'heavier language' of the iambs and the lighter choriambic phrasing. The metrical tension is a prosodic reflection of Hipparchia's situation as she finds herself existing simultaneously in multiple time-frames. Ultimately H.D.'s prosody here demonstrates how translation entails a

\footnotetext{
${ }^{84}$ Ibid., 73; cf. Hecuba 444-448. Cf. A.M. Dale, 'Metrical Analyses of Tragic Choruses: Fasc. 2 AeoloChoriambic', Institute of Classical Studies: Bulletin Supplement 21.2, London, 1981, p. 85ff.

85 See Polten, 'Spectres of Metre: English Poetry in Classical Measures, 1860-1930' (n. 66 above), p. $49 f$.

${ }^{86}$ See the comments of Samuel Coleridge: 'To adapt the Greek metres to the English language we must begin by substituting quality of sound for quantity-that is, accentuated or comparatively emphasized syllables, for what, in the Greek and Latin verse, are named long ... and vice versa, unaccentuated syllables for short' in S.T. Coleridge, The Works of Samuel Taylor Coleridge: Prose and Verse, Philadelphia, 1852, pp. 225f.

87 On accentual nature of English see D. Attridge, The Rhythms of English Poetry, Abingdon, 1982, pp. 59-75.

88 Cf. C. Collard, Euripides: Hecuba, Liverpool, 1991, p. 153f. on Hecuba 444ff.: 'In this style aeolic rhythms ... are dominant'. Nb D.S. Raven, Greek Metre, London, 1962, p. 70: 'In every aeolic line there is an essential nucleus consisting of a choriamb ——— or an extension of it'. See also M.L. West, Greek Metre, Oxford, 1982, pp. 61-66.

${ }^{89}$ It remains unclear exactly how sophisticated H.D.'s knowledge of Greek choral metres was, yet her relationship and collaborations with Pound suggests that she was aware of their characteristics. See Polten (n. 66 above), p. 209: 'Pound's poetry draws most heavily from the Aeolic metres of Greek and Latin, an array of metrical phrases (or 'cola') with the choriamb (- $\smile-)$ ) at their heart' and Prins (n. 66 above), p. 181: 'Working side by side in the British Library with Ezra Pound and Richard Aldington ... H.D. defined herself as new woman poet by training her eye on the lyric meters of Euripides and transforming his choral odes into modernist verse'.
} 
hauntological overlap of past and present that enables Hipparchia to collapse temporal distinctions and participate in chronologically impossible relationships (e.g. with her mother, Athens, Euripides, and other poets she translates).

In Gregory's analysis 'at least two epochs and two histories inhabit Hipparchia simultaneously ${ }^{\prime 90}$ and we can see that it is largely via translation and metre that she experiences and expresses her temporal disjunction. In a number of respects this is also true of H.D. 'More than an exercise in versification,' writes Prins, 'this imaginative transformation of Greek meter marks another way of being in, and out of, time not only for Hipparchia ... but also for H.D. herself' ${ }^{91}$ The confusion of the distinction between being in and out of time can be identified in Hipparchia's own simultaneous apprehension of external and internal rhythms: 'Outside a singular subtle recurring rhythm beat singular and hypnotising antistrophe to the eternal rhythm in her bound head'. 92 The text associates Euripidean chorus with the external 'subtle lap lap' of the tide that exists in a dynamic relationship with Hipparchia's own internal rhythm. The notion of these two rhythmic sets (or two temporalities) forming a whole in terms of strophe and antistrophe is neat image of the composite temporality that H.D. associates with Hipparchia and that H.D. herself seeks to explore and represent via her prosodic experimentation in this text. It is this experimentation with prosody as a means to convey multiple coexisting temporalities-and its implications in terms of free verse and contemporary ideas about time-that I now turn to in greater detail.

\section{H.D.'s Iphigenia: Time and Free Verse}

It is instructive to view free verse as not simply a reaction against 19th-century poetry, but also as a response to other cultural and historical developments: in Ian Patterson's view, free verse reflects new non-deterministic conceptions of the world and uncertainties about the nature of time. ${ }^{93}$ The modernist practitioners of free verse rejected understandings of vers libre as the wholesale dispensation of rhythmical organisation or discipline. Free verse is not so much anti-metrical as 'metrically undetermined'. ${ }^{94}$ It presents a number of different and often contradictory metrical possibilities whose openness privileges a subjective as opposed to objective experience of reading and rhythm (as we saw in the contradictory choriambic and iambic readings of the Euripidean chorus in Palimpsest). Indeed T.S. Eliot's theorisation of vers libre understands the role of metre in strikingly hauntological terms: 'The ghost of some simple metre,' he writes, 'should lurk behind even the 'freest' verse; to

\footnotetext{
${ }^{90}$ Gregory, H. D. and Hellenism: Classical Lines (n. 9 above), p. 62.

91 Prins, Ladies' Greek: Victorian Translations of Tragedy (n. 66 above), p. 200f. We might note that poet Amy Lowell wrote of H.D. that 'the everyday startles her [H.D.] as though she really were a dryad' (cited in Collecott, H. D. and Sapphic Modernism (n. 21 above), p. 104).

92 H.D., Palimpsest (n. 71 above), p. 35.

93 I. Patterson, 'Time, Free Verse, and the Gods of Modernism', in Tradition, Translation, Trauma: The Classic and the Modern, eds. J. Parker and T. Matthews, Oxford, 2011, pp. 179-80. See also M. Martin, The Rise and Fall of Meter: Poetry and English National Culture, 1860-1930, Princeton, 2012, pp. 1-15.

94 Patterson, 'Time, Free Verse, and the Gods of Modernism' (n. 93 above), p. 180.
} 
advance menacingly as we doze, and withdraw as we rouse'. ${ }^{95}$ The impact of Bergson on H.D. and her modernist peers has been demonstrated by Laci Mattison ${ }^{96}$ and, in particular, his rejection of time as a linear series of "nows" in favour of a nonlinear, personal conception of time proved influential. ${ }^{97}$ Essentially Bergsonian temporality distinguished between "real" time as subjectively experienced (durée) and "unreal" time as objectively measured (temps or clock-time) with the former corresponding to reality while the latter was an abstraction. The privileging of duration (viz., 'a continuation of what no longer exists into what does exist') ${ }^{98}$ effectively elides-not unlike a ghost-the ontological distinction between past and present: it reconfigures time as a 'virtual multiplicity' in which the present and the past are both equally parts of a single reality that comprises temporal duration. In terms of our argument, this distinction between durée and temps might be helpfully mapped out against metre and rhythm insofar as metre corresponds to external clock-time whereas rhythm corresponds to durational time. In the critical writings of modernists themselves, free verse is understood as an attempt to compose rhythmically rather than metrically ${ }^{99}$ and Meredith Martin notes that Pound saw 'rhythm as individual and authentic as opposed to the collective counterfeit of metric patterns-a divide ... between an at-once individual and universal "rhythm" and an elite, external, and artificial "meter"'. 100

It is possible to identify a parallel in visual art between free verse and the contemporary cubist movement insofar as 'cubism breaks with Renaissance perspective' and 'views objects relatively; that is from several points of view, no one of which has exclusive authority'. ${ }^{101}$ If cubism breaks with classical perspective, we might suggest that free verse breaks with classical Newtonian time (Bergsonian temps). It offers a range of rhythmic possibilities that are only actualised at the point of reading and we can see this at work in H.D.'s translation of Iphigenia at Aulis. In her introduction to the translation, H.D. explicitly rejects 'a rhymed, languidly Swinburnian verse form' and promises 'rhymeless hard rhythms' instead to preserve the 'irregular cadence of the original'. ${ }^{102}$ It also, as we shall see, allows her to capture the multiple temporal registers she sought to express in her translation:

\footnotetext{
95 T.S. Eliot, 'Reflections on Vers Libre', New Statesman, vol. VIII 204, 1917, pp. 518-19.

96 See Mattison, 'H.D.'s Institutional Imagism: Memory, Desire, and the Image in Process' (n. 39 above).

97 See S. Posman, 'Modernist Energeia: Henri Bergson and the Romantic Idea of Language', in Understanding Bergson, Understanding Modernism, eds. P. Ardoin, S.E. Gontarski, \& L. Mattison, London, 2013, pp. 213-28.

98 J. Mullarkey \& K.A. Pearson, Henri Bergson: Key Writings, London, 2002, p. 208.

$99 \mathrm{Nb}$. The imagist directive 'to compose in sequence of musical phrase, not in sequence of a metronome' (see n. 28 above).

100 M. Martin, The Rise and Fall of Meter: Poetry and English National Culture, 1860-1930, Princeton, 2012, p. 181.

101 S. Giedion, Space, Time and Architecture: The Growth of a New Tradition, Cambridge, 1941, p. 357.

102 H.D., Choruses from Iphigenia in Aulis and the Hippolytus of Euripides, London, 1919.
} 
1 I crossed sand-hills.

2 I stand among the sea-drift before Aulis.

3 I crossed Euripos' strait -

4 Foam hissed after my boat.

5 I left Chalkis,

6 My city and the rock-ledges.

7 Arethusa twists among the boulders,

8 Increases - cuts into the surf.

9 I come to see the battle-line

10 And the ships rowed here

11 By these spirits -

12 The Greeks are but half-man.

\section{Golden Menelaus}

14 And Agamemnon of proud birth

15 Direct the thousand ships.

16 They have cut pine-trees

17 For their oars.

18 They have gathered the ships for one purpose:

19 Helen shall return. ${ }^{103}$

It is worth nothing, first of all, the multiple time periods necessarily involved in the contextual background to H.D.'s translation of Iphigenia at Aulis: it is a play set at the outset of the Trojan War, produced in 405 BC at the end of a Peloponnesian War, and finally translated by H.D. in 1916 in the middle of WW1. H.D. was acutely aware of this temporal layering and notes that 'Euripides lived through almost a modern great-war period ... How would 1917 London have acclaimed such anti-war propaganda?' ${ }^{104}$ In personal terms H.D. had suffered a series of disasters that she associated with the war (most notably the stillbirth of her first child and her subsequent estrangement from her husband $)^{105}$ that likewise provided a certain thematic coherence with the destructive impact of war on family (in this case the House of Atreus) in Iphigenia at Aulis. It is a further instance of the distinction between personal and human history blurring (as demonstrated in 'Hipparchia') and H.D.'s overlaying of different temporal registers can first of all be registered on a linguistic level. As Jennifer Varney notes, H.D. (in good imagist fashion) strips the language of 'its temporal and thus narrative component' and so 'arrests notions of continuity

\footnotetext{
103 Ibid.

104 H.D., Hippolytus Temporizes \& Ion (n. 73 above), p. 277.

105 As R. DuPlessis notes in H.D.: The Career of that Struggle, London, 1986, p. 72: 'A series of formative tragedies between 1915 and 1919 (as central to H.D. as the terrible chain of family deaths were to Woolf) had marked H.D. [. . .] In 1915, there was a stillborn baby [. . . ]. Her brother Gilbert was killed in action (1918), and her father, precipitously dead in response to that loss. Metaphorically, she lost a husband, for Richard Aldington and she were permanently estranged'. See also M. Hickman \& L. Kozak, "Poppies, scarlet flowers, 'this beauty': H.D.'s Choruses from the Iphigeneia in Aulis and the First World War' (n. 8 above), p. 460.
} 
through time and undermines the logic of chronological progression'. ${ }^{106}$ The alternation of past and present tenses in 'I crossed ... I stand ... I crossed' exploits the potentialities of the aorist है $\mu \mathrm{o} \lambda \mathrm{o \nu}$ 'to reflect an action in past time or a gnomic aorist that can be translated in the present'. ${ }^{107}$ In foregrounding the dual tense possibility in the Greek, Varney writes that 'H.D. captures more faithfully the implications of the Greek text and allows the spectator/reader to experience time differently' and 'undermines temporal suppositions (e.g. that time is chronological, that we are moving forward through time, etc.)'. ${ }^{108}$

It is notable for our purposes that H.D. not only activates the multiple temporalities associated with reading Iphigenia at Aulis in 1916 in the content and language of her translation, but also in its metre. In order to best appreciate this it is necessary to remain aware of the fact that there are multiple ways-Michael Whitworth's proviso that 'rhythm [and intonation] is always an interpretation' is doubly important here ${ }^{109}$ - to read/sound free verse. We might also note that H.D. saw a 1904 performance of Iphigenia in Aulis (with Ezra Pound in the chorus) in ancient Greek and later wrote that she had been 'awakened' by the experience and that 'I felt I had heard Greek at last'. ${ }^{110}$ It would be surprising if this experience did not influence her own translation of the play twelve years later.

In its opening the translation gestures towards a rejection of regular metre with a dispondaic first line that eludes any clear metrical scheme. The second line's suggestion of iambic metre, meanwhile, breaks down with a shift to a trochaic metre (or even a choriambic rhythm if we accent Aulis rather than before in the fourth foot: 'I stand among the sea-drift before Aulis'). Instead of regular metre we find the 'irregular cadence of the original' preserved once more in a gesture towards choriambic phrasing that begins most notably in (3) where internal rhyme frustrates iambic readings and encourages a choriambic reading of 'crossed Euripos' strait' echoed by 'after my boat' in the following line. In the rest of the translation it is possible to detect a choriambic pattern if we focus our attention on individual phrases (e.g. 'I left Chalkis'; 'Arethusa'; 'twists among the'; 'increases-cuts'; 'I come to see'; 'Menelaus'; 'trees / for their oars'). In this respect we might see H.D.'s interweaving of Greek metrical cola (and possibly mimicking Euripides's own rhythm as,

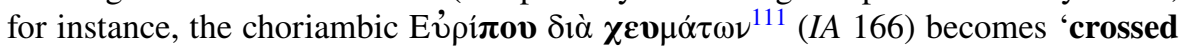
Euripos'") as effectively "summoning" the earlier playwright and disrupting traditional notions of time via the temporal logic of ghosts. The lineation of the translation, however, often obscures or frustrates these choriambic readings. In the case of (7), for example, the line is read most naturally as a regular trochaic line ('Arethusa twists among the boulders') even as it simultaneously offers a reading based around

\footnotetext{
106 J. Varney, 'The Imagist Poet as Translator: H.D. and the Translation of the Classics', PhD diss., Universitat Rovira i Virgili, 2008, p. 62.

107 Ibid., p. 63.

108 Ibid., p. 63.

109 M.H. Whitworth, Reading Modernist Poetry, Oxford, 2010, pp. 73, 76.

110 Quoted in Prins, Ladies' Greek (n. 66 above), p. 182.

111 Scanned $\bar{x}-\mathrm{u}$ u - u -. See Dale, 'Metrical Analyses of Tragic Choruses: Fasc. 2 Aeolo-Choriambic' (n. 84 above), p. 142 for metrical breakdown.
} 
two choriambic feet or phrases ('Arethusa' and 'twists among the'). While it may be unnatural to sound both feet as choriambs, the internal rhyme of 'Aresthusa' and 'the', sibilance of 'Arethusa ... twists' and slight alliteration of 'twists' and 'the', all introduce tensions that make a choriambic reading possible (or, at the very least, haunts the line's trochees with choriambic possibility). If we keep in mind H.D.'s own commitment stated in her preface to the translation (viz. to avoid regular metrical schemes) and her reputation among her modernist peers for an 'absolute personal rhythm', ${ }^{112}$ it is perhaps wise to be wary of imposing regular metronomic readings even if the lineation of the translation seems to encourage this approach.

The phenomenon we see here is not so much Eliot's notion of 'some simple metre' haunting free verse, but rather the more complex metrical cola of ancient Greek haunting simple English metres. The most consistent 'simple metre' we can detect in the translation is, incidentally, iambic trimeters (see lines 3, 4, 12, 13, 15) that are associated with Greek tragedy (albeit not the choral odes from which H.D. is translating). If we pay close attention to the aural effects of H.D.'s translation, however, it is possible to detect a choriambic undertow running through the verses. The fact that certain lines might conceivably be read as either iambic/trochaic or as choriambic prosodically imitates the (re)formation of metres and temporalities experienced by Hipparchia as H.D. explores the potential of metre to disrupt linear time. In this respect H.D.'s prosody can be seen to reflect Bergsonian ideas about time in which the separation of past, present and future is impossible and implies instead a composite form of temporality.

\section{H.D. and Freud: Translation and the Fourth-Dimension}

We are all buried alive - H.D. ${ }^{113}$

In 1933-1934, H.D. travelled to Vienna and entered into psychoanalysis with Sigmund Freud hoping to overcome writer's block. ${ }^{114}$ It worked. In 1935, H.D. completed a translation of Euripides's Ion-a translation she had been working on intermittently since $1915^{115}$ _and attributed its completion to her analysis with Freud. In a letter dating from the publication of the translation, H.D. wrote: 'I consider the ION as the Freud contribution'. ${ }^{116}$ It seems therefore that H.D.'s experience with Freud had a significant influence on her translation project and, I suggest, provided her with the means to further her investigation into the composite temporalities she first explored in her pre-Freud translations of Hippolytus, Hecuba and Iphigenia at Aulis. In her 1944 memoir of Freud, H.D. intriguingly frames her account with

\footnotetext{
112 See Prins, Ladies' Greek (n. 66 above), p. 183: 'H.D.'s verbal idiom was often cited as the clearest example of Imagism by the Imagists themselves, as they praised her poetry for "hard, direct treatment, absolutely personal rhythm, few and expressive adjectives, no inversions, and a keen emotion presented objectively' (emphasis added).

113 H.D., Tribute to Freud (n. 59 above), p. 134.

114 Ibid., 3-4.

115 See Gregory, H. D. and Hellenism: Classical Lines (n. 9 above), p. 180.

116 Quoted in Gregory, H. D. and Hellenism: Classical Lines (n. 9 above), p. 293.
} 
reference to what she describes as the "fourth-dimension" as a cipher for a realm corresponding to Freud's unconscious: 'This fourth dimension ... appears variously disguised and under different subtitles, described and elaborately tabulated in the Professor's volumes.' 117

The notion of a fourth-dimension developed by H.D. builds on her inferences regarding the spatiotemporal nature of the Freudian unconscious. While Freud does write that 'the processes of the system Ucs are timeless: i.e. they are not ordered temporally, are not altered by the passage of time, in fact bear no relation to time at all, ${ }^{118}$ his thought regarding time remained undeveloped: in a letter to Marie Bonaparte near the end of his life, Freud wrote "your comments on "time and space" have come off better than mine would have-although so far as time is concerned I hadn't fully informed you of my ideas. Nor anyone else'. ${ }^{119}$ It is possible that H.D. drew on her own pre-Freud notion of 'over-consciousness ${ }^{120}$ and its temporal implications while formulating her ideas regarding the 'fourth-dimension' as a realm outside of traditional conceptions of space and time (she writes that its temporality is not understood in terms of 'past, present, future' but in terms of 'another time-element popularly called the fourth-dimensional') ${ }^{121}$ corresponding to the Freudian unconscious. The unusual spatial status of the fourth-dimension is reflected in H.D.'s description of the four walls of Freud's consulting room with the proviso that the fourth wall (notably opposite the couch) was in fact 'largely unwalled' and opened onto a space behind 'wide-open double doors'. ${ }^{122}$ The inference is significant for our purposes insofar as in the course of H.D.'s memoir, it emerges that certain languages (such as ancient Greek or Egyptian hieroglyphics) can confuse notions of time and space and that translation itself can be a fourth-dimensional activity. We first get this impression when H.D. recounts one occasion where Freud invited her into his side-room to 'look at the things on his table' ${ }^{123}$ (significantly it was in this liminal or "fourth-dimensional" space that Freud kept his collection of antiquities). One object Freud showed to H.D. was a bronze figurine of Athene: 'She is perfect,' Freud said, 'only she has lost her spear' (emphasis in the original). In her account of Freud's comment, H.D. made the following observation:

He might have been talking Greek. The beautiful tone of his voice had a way of taking an English phrase or sentence out of its context ... The tone of his voice, the singing quality that so subtly permeated the texture of the spoken word, made that spoken word live in another dimension. ${ }^{124}$

\footnotetext{
117 H.D., Tribute to Freud (n. 59 above), p. 23.

118 S. Freud, 'On the History of the Psycho-Analytic Movement, Papers on Metapsychology and Other Works', in The Standard Edition Vol. XIV (1914-1916), ed. J. Strachey, London, 1957, pp. 159-215 (187).

119 S. Freud, 'Letter from Sigmund Freud to Marie Bonaparte, November 12, 1938', Letters of Sigmund Freud 1873-1939, ed. E.L. Freud, London, 1961, pp. 454-455 (455).

120 See H.D. Notes on Thought and Vision \& The Wise Sappho (n. 5 above), p. 24.

121 H.D., Tribute to Freud (n. 59 above), p. 23.

122 Ibid., p. 23.

123 Ibid., p. 23.

124 Ibid., p. 69.
} 
It is interesting that H.D. brings together her discussion of the fourth-dimension with the notion that Freud might be talking Greek as it situates the issue of Greek and translation firmly in realm of the fourth-dimension (we might also note, in regard to our earlier discussion of time and prosody, that H.D. describes the 'singing quality' of Freud's voice as it enters another dimension). ${ }^{125}$ The phrase 'he might have been talking Greek' is also illuminating in its expression of H.D.'s ambivalence towards certain Freudian ideas (especially regarding gender): ${ }^{126}$ the phrase can be read as colloquial shorthand for nonsense while H.D.'s fascination with all things Greek also signals a deep respect for and appreciation of Freud. The exchange concerning the statue of Athene in Freud's side-room is significant because it brings together the questions of archaeology and translation-especially as regards the fact that the antiquities in Freud's consulting room are often considered an 'objective correlative for the archaeological metaphor' ${ }^{127}$ for psychoanalysis. In Freud's earliest use of the archaeological metaphor, ${ }^{128}$ the excavations of an 'explorer' reveal the complex interplay of positivism and constructivism that characterises Freud's engagement with the past: ${ }^{129}$

If his work is crowned with success, the discoveries are self-explanatory: the ... fragments of columns can be filled out into a temple; the numerous inscriptions, which, by good luck, may be bilingual, reveal an alphabet and a language, and, when they have been deciphered and translated, yield undreamedof information about the events of the remote past, to commemorate which the monuments were built. Saxa loquuntur! ${ }^{130}$

We might notice a tension here: if the discoveries are 'self-explanatory', why the need to 'fill out' the columns and 'translate' and 'decipher' the inscriptions? Kenneth Reinhard makes the useful distinction that 'the monuments unearthed are not so much of the past as to the past'. In their commemorative function, 'the relics of antiquity ... always speak of something other than the moment which they were intended to represent'. ${ }^{131}$ The archaeological scenario undermines the idea that the "remote past" can be recovered in a strict positivist sense-viz., to be exclusively

\footnotetext{
125 See Wenthe, “The Hieratic Dance”: Prosody and the Unconscious in H.D.'s Poetry” (n. 75 above) for an analysis of H.D.'s association between prosody and the unconscious.

126 The spear-less statue of Athene has regularly been interpreted as an instance of Freud's association between penis envy and woman's physical lack of a phallus rejected by H.D. See R. DuPlessis and S. Friedman, “'Woman Is Perfect': H.D.'s Debate with Freud,” Feminist Studies, 7, 1981, pp. 417-30.

127 K. Reinhard, 'The Freudian Things: Construction and the Archaeological Metaphor', in Excavations And Their Objects: Freud's Collection of Antiquity, ed. S. Barker, New York, 1996, pp. 57-80 (58). See also R.H. Armstrong, A Compulsion for Antiquity, New York, 2005, ch. 9.

128 S. Freud, 'The Aetiology of Hysteria' in The Standard Edition Vol. X (1893-1899) ed. J. Strachey, London, 1962, pp. 165-225 (191). See K. Reinhard, 'The Freudian Things: Construction and the Archaeological Metaphor' (n. 125 above) for further overview of the archaeological metaphor.

129 See M. Leonard, 'History and Theory: Moses and Monotheism and the Historiography of the Repressed', in A Companion to Classical Receptions, eds. L. Hardwick and C. Stray, Oxford, 2007, pp. 207-218 for the tension between positivism and constructivism in Freud's conception of history.

130 S. Freud, 'The Aetiology of Hysteria' (n. 126 above), p. 191.

131 Reinhard, 'The Freudian Things: Construction and the Archaeological Metaphor' (n. 125 above), p. 61.
} 
"of the past". The excavation disturbs the "pastness" of the past since its recovery entails interaction between past and present (hence the necessary "translation" of "self-explanatory" discoveries). It undermines the very notion of timelessness insofar as although archaeology ought to provide a positivistic historical record, it nonetheless requires supplementation by the present-often in the form of contemporary translation. It is fitting that Freud's archaeological epiphany is in Latin since it highlights the relationship between the analogies of archaeology and translation in Freud's conception of psychoanalysis. ${ }^{132}$ What language, then, do Freud's saxa speak?

It is likely that Freud's saxa refer to the Rosetta Stone and its language is therefore (at least partly) Egyptian hieroglyphics. In Freud's understanding of dream interpretation as "the royal road" 133 to the unconscious, the analyst must perform 'a translation of dream-thoughts into a primitive mode of expression, analogous to hieroglyphics'. ${ }^{134}$ When H.D. offers her own description of Freudian hieroglyphics, she presents a striking evocation of a fourth-dimensional, pre-Babel linguistic paradise:

The picture-writing, the hieroglyph of the dream, was the common property of the whole race; in the dream, man, as at the beginning of time, spoke a universal language, and man, meeting in the universal understanding of unconscious or subconscious, would forego barriers of time and space. ${ }^{135}$

In a comparable passage H.D. likewise uses the idea of hieroglyphics to capture something of the complex temporalities of lived experience as she recalls describing an experience to Freud and then writing about it later:

There I am seated on the old-fashioned Victorian sofa in the Greek island hotel bedroom, and here I am reclining on the couch in the Professor's room, telling him this, and here again am I, ten years later, seated at my desk in my own room in London ... There is no clock-time ... Here is this hieroglyph of the unconscious or subconscious of the Professor's discovery and life-study. ${ }^{136}$

In her repeated use of the present tense ('here I am') to subsume three different time-frames and different places (Greece, Vienna, London) within the 'hieroglyph of the unconscious', H.D. highlights its fourth-dimensional qualities. In terms of

\footnotetext{
${ }^{132}$ See P. Mahony, 'Toward the Understanding of Translation in Psychoanalysis', Journal of the American Psychoanalytic Association, 28, 1980, pp. 461-75 (466): 'Freud deemed the following translations: Dreams ... and the analyst's interpretations'.

133 S. Freud, 'The Interpretation of Dreams (Second Part)', The Standard Edition Vol. V (1900-1901), ed. J. Strachey London, 1953, pp. 338-625 (607).

134 S. Freud, 'Introductory Lectures on Psycho-Analysis', The Standard Edition Vol. XV (1915-1916), ed. J. Strachey, London, 1963, pp. 14-238 (228).

${ }^{135}$ H.D., Tribute to Freud (n. 59 above), pp. 70-1.

136 Ibid., p. 47.
} 
H.D.'s engagement with Euripides's texts, it becomes clear that they-like Freud's saxa-also speak a "fourth-dimensional" language (in Freudian theory the "royalroad' to the unconscious is in fact supplemented by two other important psychical thoroughfares in art and religion). ${ }^{137}$ If H.D. can approach an ancient Greek text as if a dream or hieroglyph, it too should have the potential to function as ancient saxa that speak in the present and collapse boundaries of time and space by virtue of its fourth-dimensional language that can be accessed via translation/excavation. I now suggest that H.D.'s return to Ion in the 1930s-equipped with insights from Freudachieved exactly this.

\section{Fourth-Dimensional Translation: Euripides's Ion}

In Euripides's Ion, H.D. divides Euripides's text into nineteen sections intercut with prose comments. The first of these contains a joke. 'Roughly speaking, there were two types of theatre-goers in ancient Greece, as there are today,' writes H.D. 'Those who are on time and those who are late'. ${ }^{138}$ The joke announces temporality as a theme and initiates a series of comments that simultaneously draw and erase spatiotemporal distinctions and signal H.D.'s fourth-dimensional approach: ${ }^{139}$

At this moment, in the heartbeat of world progress ... there was a pause (psychic, intellectual), such a phase as we are today experiencing; scientific discovery has just opened up world-vistas ... As today, when time values and numerical values are shifting, due to the very excess of our logical deductions, so here. ${ }^{140}$

The emphasis on scientific progress and 'shifting time values' might function as 'a reference to Einsteinian notions of space/time' ${ }^{141}$ and Thomas Jenkins argues that 'quantum physics seems to run as a leitmotif throughout H.D.'s Ion, informing her ideas of temporal flux'. ${ }^{142}$ It is likely that H.D.'s thematic adoption of Einsteinian ideas was driven as much by her experience of time in her translation projects as any interest in physics. ${ }^{143}$ Einstein himself commented that 'the non-mathematician is seized by a mysterious shuddering when he hears of 'four-dimensional' things' ${ }^{144}$ and it is perhaps this 'mysterious shuddering' of the uncanny quality or untimeliness of Euripides's texts that H.D. is filtering through the lens of Einsteinian physics. When

\footnotetext{
137 See P. Rieff, Freud: The Mind of a Moralist, Chicago, 1979 [3rd edn.], p. 121: 'Every work of art is to Freud a museum piece of the unconscious'.

138 H.D., Hippolytus Temporizes \& Ion (n. 73 above), p. 150.

139 Ibid., see pp. 150, 156, 171-2, 185, 203, 222.

140 Ibid., p. 156.

141 T.E. Jenkins, 'The "Ultra-modern" Euripides of Verrall, H.D., and MacLeish', Classical and Modern Literature 27, 2007, pp. 121-45 (133); see Gregory, H. D. And Hellenism: Classical Lines (n. 9 above), p. 214.

142 Jenkins, 'The "Ultra-modern” Euripides of Verrall, H.D., and MacLeish' (n. 141 above), p. 133.

143 The example of H.D.'s autobiographical translator-protagonists, discussed above, gives a clear indication of how H.D. was attuned to the temporal aspects of translation.

144 Quoted in Jenkins, 'The "Ultra-modern” Euripides of Verrall, H.D., and MacLeish' (n. 141 above), p. 134.
} 
H.D. states that 'Greek unity gives us freedom, it expands and contracts at will, it is time-in-time and time-out-of-time together, it predicts modern time-estimates', ${ }^{145} \mathrm{Jen}$ kins argues that she is 'invoking the language of Einsteinian relativity and spiritual epiphany'. ${ }^{146}$ It is worth considering H.D.'s description of 'Greek unity' as the coming together of 'time-in-time' and 'time-out-of-time' because it reveals the nuance of H.D.'s idiosyncratic understanding of time that is sometimes obscured by her references to the 'eternal' or 'timeless' nature of Greek art. ${ }^{147}$ It is not so much that Greek literature is simply "eternal" or "timeless" but rather that it exists in multiple temporal spheres simultaneously. (In Einstein's most famous thought experiment involving a moving train, he demonstrates the relativity of simultaneity-viz., that 'events which are simultaneous with reference to the embankment are not simultaneous with respect to the train and vice versa'). ${ }^{148}$ The Ion insofar as it was produced in $413 \mathrm{BC}$ by a playwright who lived between c.484 and 406 BC does exist in a temporally discrete moment or, in H.D.'s phrase, have some relationship to 'time-in-time'. The play also, however, exists in 'time-out-of-time' due to its representation of certain essential or universal ideas that H.D. responded to in the play.

In view of this emphasis on time and the untimeliness of classical texts-and our discussion of the temporal implications of archaeology, psychoanalysis, and translation-it is significant that H.D. situates her translation in an archaeological context. In the comment introducing Ion's ekphrastic parodos (184-218), H.D. references excavations that had unearthed and reassembled the Athenian Treasury at Delphi in 1903-6. Interestingly she associates the archaeological context with Euripides's manuscript itself:

$[\mathrm{M}]$ en of almost superhuman intuition ... archaeologists of France, have managed to trace wide scattered fragments and rebuild, almost in its entirety, the ancient treasure-house of the Athenians at Delphi ... So this manuscript of the poet, Euripides, was spared when so much perished. ${ }^{149}$

The description of archaeologists recalls H.D.'s account of Freud's practice and effectively introduces her translation and the chorus' admiration of the frieze in a psychoanalytic-archaeological context. ${ }^{150}$ Freud would have little trouble "translating" or "excavating" the frieze and the chthonic-olympian struggle of the gigantomachy in terms of unconscious and conscious drives. The frieze is an artwork within an artwork whose thematic importance to the wider play has been noted insofar as it is effectively repeated on-stage in Kreousa's attempt to murder Ion. ${ }^{151}$ This pattern

\footnotetext{
145 H.D., Hippolytus Temporizes \& Ion (n. 73 above), p. 185.

146 Jenkins, 'The "Ultra-modern” Euripides of Verrall, H.D., and MacLeish' (n. 141 above), p. 134.

147 See for example H.D. Notes on Thought and Vision \& The Wise Sappho (n. 5 above), p. 23.

148 A. Einstein, Relativity: The Special and General Theory, New York, 1920, p. 32.

149 H.D., Hippolytus Temporizes \& Ion (n. 73 above), p. 162.

150 Cf. H.D., Tribute to Freud (n. 59 above), p. 14: 'Fragmentary ideas, apparently unrelated, were often found to be part of a special layer or stratum of thought and memory, therefore to belong together; these were sometimes skillfully pieced together like ... exquisite Greek tear-jars'.

151 See G. Martin, Euripides, Ion: Edition and Commentary, Berlin, 2018, p. 175f.; C. Segal, 'Euripides's Ion: Generational Passage and Civic Myth', Bucknell Review, 43, 1999, pp. 77-9; K. Lee, 'Mood
} 
of repetition of primordial struggle informs Charles Segal's analysis of the tragedy as a dialectic of near-and-far that 'plays incessantly with the simultaneous nearness and remoteness of the mythical world' ${ }^{152}$ Segal's reading is useful to our discussion: it is not simply that the disciplines of psychoanalysis, archaeology and translation can all be understood as dialectics of near-and-far-but more importantly, H.D.'s spatiotemporal conception of a fourth-dimension entails the collapse of precisely this near-far distinction.

It is important to note that the emphasis on time and its non-linearity not only reflects 20th-century intellectual developments, but also has a basis in Euripides's text. Kevin Lee has suggested that Kreousa and Ion represent opposing temporal experiences as Ion's tenuous grip on his past confines him to an eternal present whereas Kreousa's fixation on the past traps her there. ${ }^{153}$ This analysis informs Naomi Weiss's persuasive psychoanalytic reading arguing that the presentation of Kreousa amid patterns of repetition and duplication can be read against Freud's theory of repetition compulsion and inability to escape the past. ${ }^{154}$ Kreousa recounts the story of her rape and exposure of Ion on four occasions ${ }^{155}$ and in Weiss's analysis, this reflects Freud's observation that traumatised individuals 'repeat the repressed material as a contemporary experience instead of ... remembering it as something belonging to the past'. ${ }^{156}$ Interestingly, Kreousa's temporal dislocation and exclusion from the present is emphasised by H.D.:

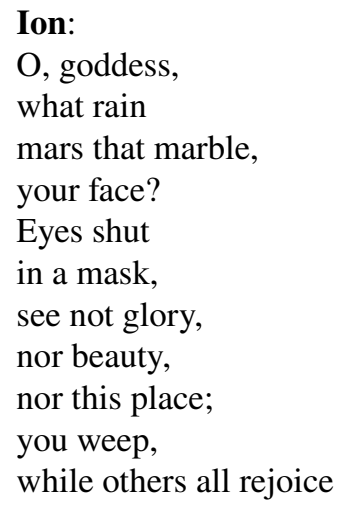

\footnotetext{
Footnote 151 (continued)

and Time in Euripides's Ion', Tragedy and the Tragic: Greek Theatre and Beyond, ed. M.S. Silk, Oxford, 1996, pp. 85-109.

152 Segal, 'Euripides's Ion: Generational Passage and Civic Myth' (n. 151 above), p. 77.

153 See Lee, 'Mood and Time in Euripides's Ion' (n. 151 above).

154 See N. Weiss, 'A Psychoanalytical Reading of Euripides's Ion: Repetition, Development and Identity', Bulletin of the Institute of Classical Studies, 51, 2008, pp. 39-50.

155 Cf. Ion 336-56; 859-922; 936-965; 1478-99.

156 S. Freud, 'Beyond the Pleasure Principle', in The Standard Edition Vol. XVIII (1920-1922), ed. J. Strachey, London, 1955, pp. 1-63 (17); cf. Weiss, 'A Psychoanalytical Reading of Euripides's Ion: Repetition, Development and Identity' (n. 154 above), p. 40.
} 
in this splendour,

the temple

of Loxias.

Kreousa:

$\mathrm{O}$, fair,

$\mathrm{O}$, strange voice,

it is right

that you ask

why I weep;

I looked on this house,

I was caught

by an ancient regret;

I stood here,

I was far off. 157

The prose comment preceding this exchange undermines a sense of passing time: 'The Queen of Athens stands before us. How long has she been standing? She has always been standing there. She seems, simply, a temple property that we have, so far, neglected' ${ }^{158}$ H.D.'s major alteration to the original reinforces this impression and transforms Kreousa into a statue ('that marble, / your face?'). ${ }^{159}$ The obvious mythic parallel here is Niobe: a woman whose petrification after the death of her children preserved her grief and excluded her from the present. This disruption between past and present and arresting of the progression of time entailed by petrification effectively presents Kreousa as "buried alive" by the past and psychologically stranded in the cave where the rape occurred. There is also a spatial dimension to Kreousa's alienation from the present as she remarks 'I stood here, / I was far off'. The emphasis on Kreousa's preoccupation with the past resembles-as Weiss would argue - the 'symptoms described by Freud in cases of fixation to traumas: patients seem to be "fixated" to a particular portion of their past ... and were for that reason alienated from the present and the future'. ${ }^{160}$

The initial emphasis on the petrified pastness of Kreousa, however, is gradually undermined over the course of the translation. The comment following Kreousa's entrance signals the imminent development as Kreousa prepares to broach the subject of her 'ancient regret': 'A woman is about to step out of stone, in the manner of a later Rodin. It is impossible ... not to swing forward into a-to 5th-century Greece-distant future'. ${ }^{161}$ (We might recall Freud's saxa loquuntur! here). It is from this point on that Kreousa appears to make therapeutic progress via a process of repetition/translation/excavation (effectively intra-lingual translations or

\footnotetext{
157 H.D., Hippolytus Temporizes \& Ion (n. 73 above), pp. 171-2.

158 Ibid., p. 171.

159 Cf. D. Kovacs, Euripides IV, Cambridge, 1999, p. 345 for literal translation: 'You shut your eyes tight and moisten your noble cheek with tears'.

160 Weiss, 'A Psychoanalytical Reading of Euripides's Ion: Repetition, Development and Identity' (n. 154 above), p. 41.

161 H.D., Hippolytus Temporizes \& Ion (n. 73 above), p. 172.
} 
paraphrases) in which she revisits her trauma to overcome the pastness originally emphasised. In the first instance of this repetition Kreousa only tells Ion that 'a crime was done there [sc. Athens' 'Great Rocks']' and that she has come to Delphi 'for a friend's sake', ${ }^{162}$ while touching vaguely on the misdeed of the "friend" in four monosyllabic words: " - hid in the rocks - '. ${ }^{163}$ This line marks Kreousa's first (albeit concealed) acknowledgement of her exposure of Ion and begins a process whereby she repeats it in increasing detail. The prose comment introducing Kreousa's monody at 859ff. and the first explicit acknowledgement of her rape and abandonment of Ion-identified by Weiss as a psychologically significant 'breaking of a long silence' and eruption of 'repressed knowledge' ${ }^{164}$ _asks 'how can we believe that 500 B.C. and A.D. 500 (or our own problematical present) are separated by an insurmountable chasm?" ${ }^{165}$ Here H.D. undermines temporal distinctions just at the moment Kreousa confronts her past directly and recounts it in painful detail while also assuming responsibility: 'I left him there on the rocks' ${ }^{166}$ Kreousa goes on to say 'my heart broke $-\ldots$ - his small hands reached $-\ldots$ - seeking my breast__, 167 in a therapeutic or cathartic expression of past trauma (there is a sense that she is 'remembering' rather than 'repeating' here). In her final re-telling of her 'ancient regret', Kreousa has recognised Ion and his physical presence enables her to confront the present (and anticipate the future with Ion as king of Athens) even as she recounts past trauma ('I left you alone in the desert / for foraging hawks / and death - ' $)^{168}$ in a full experience of different temporal registers.

It is possible to see Kreousa's reconciliation with Ion and psychological relief in temporal terms: it marks the end of Ion's alienation in the present and Kreousa's alienation in the past as Ion gains a past while Kreousa gains the present as she escapes her spatiotemporal confinement. Once she is no longer trapped in a specific time and space, H.D.'s Kreousa emerges as a fourth-dimensional 'figure of a new worldwoman'. ${ }^{169}$ Her fourth-dimensionality is emphasised by the fact Kreousa is no longer simply a woman but specifically a 'world-woman' and therefore presumably an archetypal woman figure for whom spatiotemporal considerations are irrelevant. It is a transformation that sees Kreousa, as world-woman, described by H.D. as a 'queen' and a 'goddess' and H.D. goes as far as to write 'the woman, has failed' as Kreousa is transformed into 'the very embodiment of that Virgin Mother of her city, Athené, strength, power, wisdom with the abstraction of Time'. ${ }^{170}$ In this note H.D. once again elides the 'insurmountable chasm' between the traditions of ancient Greece and Christianity as she enfolds the 'Virgin Mother' and 'Athené' into the figure of Kreousa:

\footnotetext{
162 Ibid., p.177.

163 Ibid., p. 177.

164 Weiss, 'A Psychoanalytical Reading of Euripides's Ion: Repetition, Development and Identity' (n. 153 above), p. 43; cf. K. Zacharia, Converging Truths: Euripides's Ion and the Athenian Quest for Self Definition, Leiden, 2003, p. 96.

165 H.D., Hippolytus Temporizes \& Ion (n. 73 above), p. 203.

166 Ibid., p. 212.

167 Ibid., p. 216.

168 Ibid., p. 251.

169 Ibid., p. 203.

170 Ibid., pp. 215, 203.
} 
Kreousa the individual woman with a personal history has been lifted from "time-intime" and reconfigured into an archetypal female figure (or 'world-woman') of a queen or goddess who exists simultaneously in "time-out-of-time".

It is not only Kreousa, however, who gains fourth-dimensional characteristics via a process of repetition/translation/excavation within the text: it is also possible to argue that Euripides's text itself undergoes a similar process as its prima facie pastness is undermined in H.D.'s pursuit of fourth-dimensional translation. Notably-in view of her parallel between excavation and translation-H.D. adopts an archaeological approach in her translation. The division of Ion into sections fragments the text and reconstructs it: ${ }^{171}$ Donald Carne-Ross notes of this approach that H.D. essentially 'took her play to pieces, broke it down to a pre-verbal level and then set about reconstituting it in her own terms' ${ }^{172}$ It is possible to consider this approach in Freudian terms. In reducing the play to a 'pre-verbal level' might we suggest that H.D. attempted to access its "hieroglyphic" meaning privileged by Freud in his own practice of "translation" in dream interpretation?

It is an approach most evident in the extended passages of stichomythia and outlined in H.D.'s comment preceding the exchange between Ion and Kreousa at 264-368. ${ }^{173}$ 'The broken, exclamatory or evocative vers-libre which I have chosen to translate the two-line dialogue, throughout the play, is the exact antithesis of the original. Though concentrating and translating, sometimes, ten words, with two, I have endeavoured in no way, to depart from the meaning'. ${ }^{174}$ It is via this approach that we can best identify the fourth-dimensional qualities of H.D.'s translation as we compare her text with a literal translation of Ion 271-81:

Ion. And she gives him, just as shown in paintings ...

Kr. Yes - to the daughters of Kekrops, never seen.

Ion. I have heard these daughters opened the vessel of the goddess.

Kr. And that is why dying, they spattered the rocky cliff.

Ion. Well, is the other story then false or true?

Kr. What thing do you ask? For I am not restless with leisure.

Ion. Did your father, Erekhtheus, sacrifice your sisters?

Kr. On behalf of the country, he sacrificed those maidens.

Ion. How were you alone saved of your sisters?

Kr. I was just a new-born babe in the crook of my mother's arms.

Ion. Is it true that a cleft in the earth hides your father?

Kr. Blows of the sea-god's trident destroyed him.

Ion trans. Kovacs $(271-81)^{175}$

\footnotetext{
171 It is likely that H.D. was influenced in this decision by Leconte De Lisle's 1913 French prose translation of Ion, which was organised with similar divisions and which H.D. followed. See S. Friedman, Analyzing Freud: The Letters of H.D., Bryher, and their Circle, New York, 2002, p. 529.

172 D. Carne-Ross, 'Translation and Transposition', The Craft \& Context of Translation: A Symposium, eds. W. Arrowsmith \& R. Shattuck, Austin, 1961, pp. 3-21 (8).

173 The other passages of stichomythia are Ion 255-368; 517-562; 934-1029; 1284-1355.

174 H.D., Hippolytus Temporizes \& Ion (n. 73 above), p. 174.

175 Kovacs, Euripides IV (n. 159 above), pp. 348-50.
} 


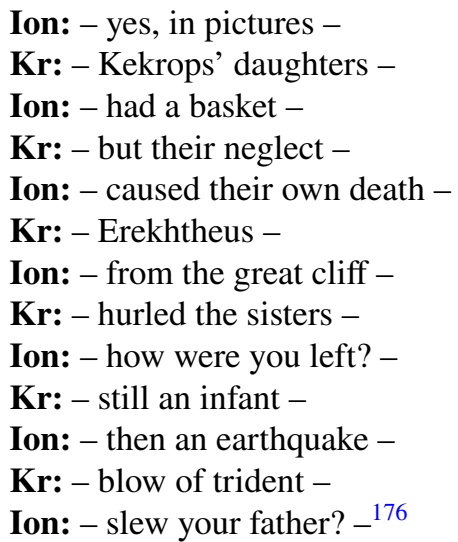

H.D. typically ignores the Athenian political or historical content in her translations and in her translator's note to Ion, ${ }^{177}$ she acknowledges excising the 'latter part of the epilogue, which is historical narrative, having to do with a prophecy, concerning the future of the Ionian race'. ${ }^{178}$ Essentially H.D. excises the historical and political detail that situates the text at a discrete moment in the remote past because it obscures the fourth-dimensional qualities of the text. Whereas Euripides presents a condensed account of three generations of complex Athenian history, H.D. does not explicate this history but reduces the detail in order to present the story in as general terms as possible. 'The Athenian "details" [excluding proper names] of the passage', notes Jenkins, 'have been dropped: part of H.D.'s programme of "modernising" the Ion is to strip the Greek to its essentials'. ${ }^{179}$ The fragments of the dialogue-broken into non-grammatical snippets by em-dashes_-gesture towards an almost 'preverbal' mode of expression as H.D. presents the narrative (as if responding to Ion's allusion to a pictorial tradition) in a series of hieroglyphic images: 'trident'; 'earthquake'; 'basket'; 'cliff'; 'infant'.

One consequence of H.D.'s approach is a temporal flattening and the omission of Ion's question at 275 obscures the generational passage of Athenian history: in H.D.'s version, there is no 'other' story and the sense of linear temporal progression is lost in collapsing Athenian history into a series of images. It is not only the intuitive sympathy of mother and son that H.D. captures in the sequence of foursyllable lines that echo each other metrically-but also the fusion of the two separate models of temporality outlined by Lee. In Gregory's analysis, H.D. combines 'discrete voices ... into an associational single voice': ${ }^{180}$ I would add that it is not just discrete voices, but two previously discrete temporalities or experiences of time that are combined. The reduction of detail opens the dialogue to more temporal possibilities: Ion's references to 'neglect', 'basket' and being 'left' while 'still an infant'

\footnotetext{
176 H.D., Hippolytus Temporizes \& Ion (n. 73 above), pp. 174-5.

177 See Gregory, H. D. and Hellenism: Classical Lines (n. 9 above), p. 209.

178 H.D., Hippolytus Temporizes \& Ion (n. 73 above), p. 149.

179 Jenkins, 'The "Ultra-modern" Euripides of Verrall, H.D., and MacLeish' (n. 141 above).

180 Gregory, H. D. and Hellenism: Classical Lines (n. 9 above), p. 211.
} 


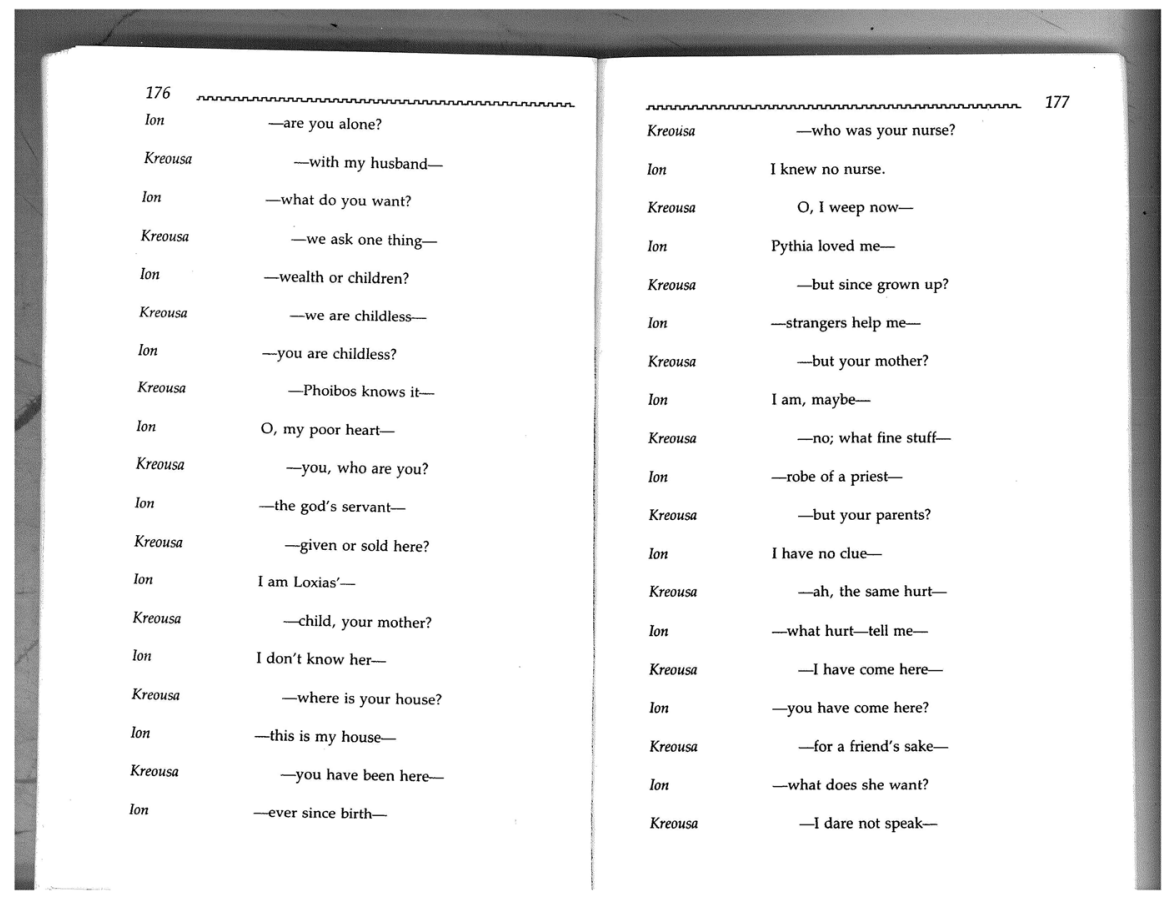

Fig. 1 Pages 176-177 of Hippolytus Temporizes \& Ion by H.D. (New Directions, 2003)

not only recount earlier Athenian history, but also intuit his own personal history (in fact H.D.'s somewhat forced translation of '̇ $\xi \varepsilon \sigma \omega \theta \eta\rceil s$ as 'left' encourages this inference). The future is also implicated as the form of the dialogue foreshadows Ion and Kreousa's recognition and reconciliation. H.D. undermines the pastness of the events described in favour of a dialogue that simultaneously gestures towards past, present and future in such a way as to capture the composite 'time-element' of the fourth-dimension.

In spite of H.D.'s excision of Athene's prophecy at 1581-88, its promise of historical continuity is actually reformulated in terms of cultural continuity: the emphasis on Ion's historical legacy ('called by the name Ionians after this man' (Ion 1587-8)) becomes a cultural legacy. In the archaeological comments, H.D. writes 'now sharp Ionic columns start up, shafts of unblemished marble point the way to a return; worship the eternal. Indestructible beauty lives'. ${ }^{181}$ This idea recurs at the end of the translation. 'While one Ionic column stands ... that name shall live' ${ }^{182}$ Instead of

\footnotetext{
181 H.D., Hippolytus Temporizes \& Ion (n. 73 above), p. 162.

182 Ibid., p. 256.
} 
Ion's historical legacy — and its spatial and temporal constraints-H.D. highlights a cultural or aesthetic legacy that transcends such constraints. H.D.'s translation might likewise be understood as a process of excavation: it recovers and reassembles (like the archaeologists at Delphi) Euripides's text so that it can exist like those ionic columns as an artefact in which spatiotemporal distinctions disappear. It is perhaps worth noting that the stichomythia translated by H.D. extends down her pages like slender (Ionic) columns: (Fig. 1). ${ }^{183}$

We can here identify the fourth-dimensional nature of H.D.'s translation as itlike the antiquities in Freud's side-room-upends traditional notions of time and space. The translated text is excavated from Euripides's Greek and stands like columns excavated at Delphi: its column-like format offers an insight into a composite temporality and universality that Euripides's texts had always suggested to H.D. and that Freud's ideas regarding art, dreams and the unconscious later confirmed.

\section{Conclusion}

Let us now return-by way of conclusion-to H.D.'s 1925 comment with which I inaugurated this discussion: 'I seem a very between-worlds person'. ${ }^{184}$ It is notable that the figures we have encountered in H.D.'s work are not only frequently themselves "between worlds", but also regularly turn to some form of translation to negotiate their in-betweenness. It is this ghostly aspect of translation as a literary form predicated on the temporal-ontological status of being "between worlds" that informs the respective Derridean and Freudian approaches that have shaped this paper. It is now possible to draw these approaches together in H.D.'s Ion translation and the eventual reunion of Kreousa and Ion. If Ion represents H.D.'s imagism and modern classicism as a crystalline male youth who exists in a timeless present while Kreousa represents traits more closely associated with romantic hellenism such as femininity, emotion, and alienation from present, then what can we, finally, infer from their union?

The union of Kreousa and Ion can ultimately be read against the terms that have preoccupied us in this paper: it reflects H.D.'s understanding of the 'freedom' derived from 'Greek unity' that 'is time-in-time and time-out-of-time together' and the composite temporality H.D. sought to express in her translations. We might expand H.D.'s notion of 'Greek unity' to also encompass the coming together of modern classicism and romantic hellenism; present and past; and masculine and feminine that characterises H.D.'s own translation project and engagement with Euripides. The play ends with Kreousa not linguistically, temporally or psychologically "out-of-joint" with respect to either herself or H.D.: she is not simply a distant figure from Athenian myth or Euripidean drama, but also and simultaneously a 'new world-woman' ${ }^{185}$ whose "original" language, time and geographical location are incidental. In the end, we can understand Euripides's texts as providing 'clear

\footnotetext{
183 Pages 176-77 of H.D.'s Hippolytus Temporizes \& Ion (n. 73 above).

184 Quoted in Friedman, Penelope's Web (n. 1 above), p. 19.

185 H.D., Hippolytus Temporizes \& Ion (n. 73 above), p. 203.
} 
entrances' to a "fourth-dimension" (or "over-world consciousness") in which binary distinctions drawn along lines of gender, cultural, linguistic or spatiotemporal concerns can successfully coexist as evidenced in H.D.'s composite translations. It seems appropriate that Euripides's Ion was H.D.'s last translation project proper: ${ }^{186}$ it marks the end of $a^{187}$ engagement ${ }^{188}$ with translation ${ }^{189}$ that effectively shaped her poetics as she pursued a culturally and temporally composite approach to translation that Euripides' Ion is the most striking example of.

Open Access This article is licensed under a Creative Commons Attribution 4.0 International License, which permits use, sharing, adaptation, distribution and reproduction in any medium or format, as long as you give appropriate credit to the original author(s) and the source, provide a link to the Creative Commons licence, and indicate if changes were made. The images or other third party material in this article are included in the article's Creative Commons licence, unless indicated otherwise in a credit line to the material. If material is not included in the article's Creative Commons licence and your intended use is not permitted by statutory regulation or exceeds the permitted use, you will need to obtain permission directly from the copyright holder. To view a copy of this licence, visit http://creativecommons.org/licen ses/by/4.0/.

Publisher's Note Springer Nature remains neutral with regard to jurisdictional claims in published maps and institutional affiliations.

186 Nb. R. Duncan, The H.D. Book, Berkeley, 2011, p. 210 identifies Euripides's Ion as the 'pivot' in H.D.'s career before she turned towards the expansive, associational style of her later (post-Freud) work.

187 D. Albright, 'Modernist Poetic Form', in The Cambridge Companion to $20^{\text {th }}$ Century English Poetry, ed. N. Corcoran, Cambridge, 2008, pp. 24-41.

188 H.D., Collected Poems 1912-1944., ed. L.L. Martz, New York, 1986.

189 R. Aldington et al., Des Imagistes: An Anthology, London, 1914. 